\title{
THE GETTY HEXAMETERS AND GREEK TRAGEDY
}

\author{
Luigi Battezzato $\star-$
}

Scuola Normale Superiore, Pisa, Italy

${ }^{\star}$ Corresponding author. Email: luigi.battezzato@sns.it

The present article aims to show that several passages of Greek tragedy make use of language present in the Getty Hexameters, especially in contexts where incantations and protection of the city are mentioned. The Getty Hexameters were written on a lead tablet at the end of the fifth century BC in Sicily (Selinus or, more likely, Himera). The article argues that the composition of the text predates the lead tablet by several decades (section 2). It focuses on similarities in structure and language that involve Soph. fr. 535 (section 4), Aeschylus' Oresteia (section 5), Sophocles' Oedipus Tyrannus (section 6) and Euripides' Hecuba (section 8). It also suggests that Plato (section 7) and late antique poetry and prose (section 9) reuse some of the linguistic elements of the incantatory tradition of the Getty Hexameters.

\section{Introduction}

A passage of Timaeus of Tauromenium (fourth/third century BC) discusses the importance of the myth and cults of Demeter and Persephone in Sicily. He claims that Carcinus, a fourth-century BC tragic poet (from Athens or possibly from Akragas), ${ }^{\mathrm{I}}$ knew the cults of Demeter and Persephone as practised in Syracuse, and was influenced by them in his poetry. This is the fragment of Carcinus quoted by Timaeus: ${ }^{2}$

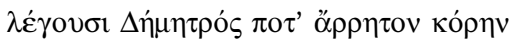

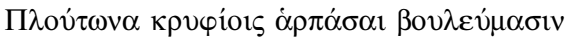

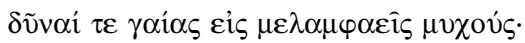

\footnotetext{
${ }^{\top}$ This paper was presented in Oxford, Lyon and Pisa. The final version was written during my period as Visiting Fellow at All Souls College, Oxford, in the 2019-2020 academic year. I would like to thank L. Prauscello, D. Colomo, E. Cingano, G. B. D'Alessio, S. Scullion and the people who offered suggestions and corrections at the oral presentations, as well as the anonymous readers for the journal. This does not imply that all the people involved agree on the interpretation suggested here. I alone bear responsibility for any remaining errors of fact or judgement.

I See Snell and Kannicht (I986) ad 235 .

2 See Carcinus 70 F 5.I-3 TrGF; Timaeus 566 F 164 Jacoby, from Diodorus Siculus 5.5.I.
} 
Demeter's daughter, her whom none may name, By secret schemings Pluton, men say, stole, And then he dropped into earth's depths, whose light Is darkness (tr. Oldfather (I939))

The underworld is described by the striking oxymoronic phrase $\gamma \alpha i \alpha \varsigma \ldots \mu \varepsilon \lambda \alpha \mu \varphi \alpha \varepsilon i \varsigma$

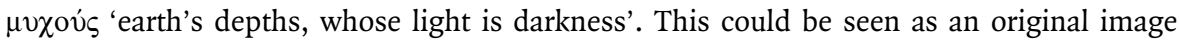
created by an inventive poet. In 20II, David Jordan and Roy Kotansky published the text of a lead tablet from Sicily, dated to the fifth or fourth century BC, which uses the same oxymoronic image to describe the underworld. The text is generally known as the Getty Hexameters, from the name of the museum that houses the artefact. The Getty Hexameters mention Persephone and Demeter, and call the underworld a 'place whose light is darkness' (GH (= Getty Hexameters) 8-Io):

\begin{tabular}{|c|c|}
\hline 8 & 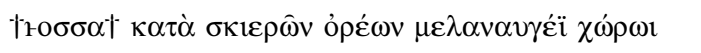 \\
\hline 9 & 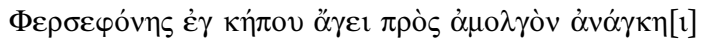 \\
\hline IO & 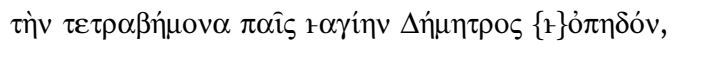 \\
\hline
\end{tabular}

$\uparrow \ldots+$ the child, from the shadowy mountains in the black-lit place, Leads from Persephone's garden by force to its milking The four-footed attendant of holy Demeter... ${ }^{3}$

The similarities with Carcinus in context and phrasing are striking. The text, of Sicilian origin, is linked to incantations and, according to many interpreters, mystery cults. Carcinus slightly adapts the language because of the different metrical context ( $\mu \varepsilon \lambda \alpha \mu \varphi \alpha \varepsilon i \varsigma$ is much easier to insert in iambs than $\mu \varepsilon \lambda \alpha v \alpha v \gamma \eta \dot{\eta}$, suitable for dactyls). Carcinus' text itself, by using the word ö $\rho \rho \eta \tau$ v 'unspeakable', 'secret' in line I, alludes to the taboo on Persephone's name: her name cannot be revealed to people who are not initiated into the mysteries (Pausanias 8.37.9). The adjective 'unspeakable' thus functions as an allusion to mysteries. ${ }^{4}$ Several other tragic texts had already used this phrase (Eur.

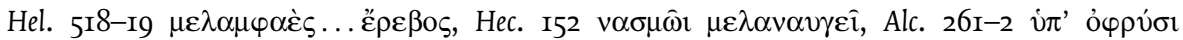



3 Text and translation from Janko (2015). I print $\tau \varepsilon \tau \rho \alpha \beta \eta \mu \nu \alpha \alpha$, as in the tablet (see the editions of Faraone and Obbink (2013b), Lucarini (2018) and Furley (2019)), not the correction $\tau \varepsilon \tau \rho \alpha \beta \alpha$ jovo $\alpha$ (Janko (2013) 47-8; the form with alpha is found in a fifth/sixth-century $\mathrm{AD}$ curse tablet from Antioch: see Hollmann (2003) 76 . I thank D. Colomo for drawing my attention to this document. Janko reads $\{r\}$ 'O $\sigma \sigma \alpha$ at 8 as a proper name of the 'child' ('Ossa'); this is extremely unlikely, as no other similar names are indicated, but no clearly convincing alternative has been suggested. The text is probably corrupt. (I987) 4-5, 73-4 and passim; Parker (2005) 327-68; Bremmer (2014) I-20, I66-79, with further references. 



been discussed so far, and from a very different perspective. Some scholars suggest that the Getty Hexameters imitate Soph. fr. 353.2 TrGF and Eur. Hec. 152. ${ }^{5}$ Others argue that both tragedy, in these two cases, and the Getty Hexameters simply use traditional poetic language. ${ }^{6}$

This article aims to show that several other passages of Greek tragedy make use of language present in the Getty Hexameters, especially in contexts where incantations and protection of the city are mentioned. Tragedy incorporates and readapts many elements taken from earlier genres of poetry, from epic to lyric; the sung and spoken performances of choruses and characters often allude to these genres within the tragic setting. ${ }^{7}$ Tragedy also often alludes to magical texts and performances. ${ }^{8}$ The publication of the Getty Hexameters allows modern interpreters to perceive the background of many tragic passages and the allusion to magical practices that would otherwise have eluded attention.

The lead tablet on which Getty Hexameters are inscribed was donated to the Getty Museum in I98I together with the lex sacra of Selinus, also on lead, and with 'three curse tablets of the early $5^{\text {th }}$ c. BCE', also from Sicily. ${ }^{9}$ Several complete editions of the Getty Hexameters have been published, ${ }^{\text {IO }}$ as well as studies on specific passages. ${ }^{\text {II }}$

Preparing a new full diplomatic and philological edition of the text, including a critical apparatus and palaeographic notes, is beyond the scope of this paper. The line numbers used (from I to 50) are those provided in the edition printed in Faraone and Obbink (2013b). ${ }^{\mathrm{I2}}$ The text of the relevant sections will be provided, when necessary, for the

5 See esp. Bremmer (2013); Janko (2013) 55 agrees with Bremmer that 'the striking parallels with Sophocles' Rhizotomoi [fr. 353.2] and Euripides' Hecuba strongly suggest that the poet who composed these spells was familiar with some Attic tragedies of the latter half of the fifth century'. However, Janko (2013) 47 also considers the possibility that 'Euripides [in Hec. I52 $^{2}$ is creating a tragic variation on the phrasing of this very poem'.

6 Bettarini (2012) II5: 'patrimonio poetico comune', quoted with approval by Lucarini (2019) 30.

7 See e.g. Herington (1985); Swift (2010); Weiss (2018), with further references.

8 See e.g. Faraone (1985), (I994); Graf (1997) 22, 8, 98, I94; Dickie (200I) 29-3I, 35-9, 55-8, 6I, 65, 80, 87-8, 93-4; Faraone (2008); Mueller (2011); Curti (2012), with further references. These texts also discuss the definition of 'magic', a complex problem that cannot be tackled in this paper. On magic in Greece see in general Graf (1997); Dickie (200I); Parker (2005) Ir6-35; Collins (2008); Ogden (2009); Kindt (2012) 90-I22; Edmonds (2019), with further references and extensive discussions.

9 Quotation from Jordan and Kotansky (20II) 55, who also provide other details about these artefacts. See the next note for other editions of the Getty Hexameters. Janko (2015) I-2 offers details about the acquisition process and the study of the Getty Hexameters before publication. On the sacred law see Jameson et al. (1993); Robertson (2010); Iannucci et al. (2015), with further references. On the curse tablets see Kotansky and Curbera (2004). For collections and publications of other related inscriptions from the same area see Bettarini (2005a), (2005b); Rocca (2009); Jordan et al. (2014).

Io See Janko (2013), (2015); Lucarini (2018); Furley (2019). Janko (2015) offers the most detailed report of readings and textual suggestions and is based on direct examination of the tablet (see Lapatin (2013); Janko (2015) 2 n. 7).

II See esp. Bettarini (2012); Johnston (2014); Caliva (2016); the papers in Faraone and Obbink (2013a) and Antonetti (2018a) (esp. Tribulato (2018b); Cingano (2018), on textual and linguistic problems), and the bibliographical references in these works and in those quoted in the previous note.

I2 In other editions, line numbers start again at each column/side (esp. the authoritative editions of Jordan and Kotansky (20II) and Janko (2015)). Starting the numbering again at each column/side is more accurate, in that an unascertainable number of lines have probably been lost at the end of each column. However, it is 
convenience of the reader. The translation, unless otherwise noted, is that of Janko (2015), occasionally slightly adapted. ${ }^{\mathrm{I}}$ Many points of text and interpretation are uncertain. For reasons of space, textual and interpretive problems will be discussed only when they affect the point discussed in this paper.

Section 2 will illustrate in brief the debate on the date and origin of the Getty Hexameters, arguing that the text was written in Sicily (Selinus or, more likely, Himera), and that the composition of the text predates the artefact (end of the fifth century BC) by several decades. Linguistic and epigraphic data suggest that it is highly unlikely that late fifthcentury tragedy influenced the text of the Getty Hexameters as a whole. The main argument of the article (sections 3-9) does not depend on conclusion of this (more technical) section. Sections $3^{-9}$ can be read independently from section 2.

Section 3 offers a brief overview of the content of the Getty Hexameters.

Sections $4-6$ and 8 discuss the interaction between the Getty Hexameters and Greek tragedy, focusing on similarities in structure and language that involve Soph. fr. 535 (section 4), Aeschylus' Oresteia (section 5), Sophocles' Oedipus Tyrannus (section 6) and Euripides' Hecuba (section 8). Plato (section 7) and late antique poetry and prose (section 9) reuse some of the linguistic elements of the incantatory tradition that reverberate in tragedy.

\section{Context, date and language}

\subsection{Texts and copies}

The Getty Hexameters are part of a constellation of texts. Several sections of the Getty Hexameters are transmitted, in identical or similar form, alone or in combination with other texts, in a number of other documents, spanning from the early fifth century BC to the fourth century $\mathrm{AD}$, and coming from different part of the ancient world (Sicily, Crete, Egypt, Rome). ${ }^{\mathrm{I}}$

Richard Janko attempts to reconstruct the 'archetype' of all the extant texts, starting from the Getty Hexameters, the longest text. ${ }^{15}$ It is however possible the Getty Hexameters (or their

unfortunately unlikely that the missing lines will emerge soon or at all. The continuous line numbering system is easier and is used in many publications: Faraone and Obbink (2013a); Janko (2013); Caliva (2016); Lucarini (20I8); Furley (20I9)). It is in any case plausible that the Getty tablet included the lines printed as col. ii lines $2 \mathrm{I}-2$ in Janko (2015) 6; these lines survive in other texts (L $\Phi$ : see below for the sigla) and can be reconstructed at least in part; only traces of a few letters survive in the Getty tablet. This insertion does not change the line numbers, and Janko (2015) 6 thinks that line 42 (in the numbering adopted here) was the last line of the column.

I3 The presentation of the text is simplified: papyrological underdots and the symbols used by Janko to indicate corrections are omitted. The papyrological 'corner brackets' $\mathrm{L}\lrcorner$ indicate that the text is missing from the Getty tablet but is found in parallel texts. The text is often uncertain, and many supplements printed by Janko in the lacunae are to be considered exempli gratia, not certain.

I4 See Jordan and Kotansky (20II) 54 n. 3; Bettarini (20I2) III; Del Monaco (20I2) I3I; Lucarini (20I8) 25.

I5 Janko (2013), (2015). Janko, even if he attempts at reconstructing an 'archetype', still uses the Getty text as a basis for the reconstruction, writing 'col. i', 'col. ii' etc.; these are the columns of the Getty Hexameters, though, not those of the archetype (which we cannot reconstruct in its materiality, unlike that of e.g. Lucretius: Timpanaro (2005)). Janko (I984) and (2016), following the lead of West (I975) and Lloyd-Jones (I975) 225, offered reconstructions of the 'archetype' of the Golden lamellae for the dead. Individual differences between these texts are pointed and 
model) were written assembling pre-existing different shorter texts. This longer version is not necessarily the archetype of the shorter text. ${ }^{16}$ The shorter texts may have different linguistic and dialectal characteristics from that of the Getty Hexameters. Moreover, it is clear that the text was heavily changed in some copies: lines 36-4I of the Getty Hexameters are written as prose, but clearly derive from a hexametrical text. ${ }^{17}$ The present article will focus on the Getty copy as a specific version of a widespread group of similar texts.

\subsection{Writing, the date of the tablet and the date of the text}

The first editors, Jordan and Kotansky, suggest that the tablet was written in Sicily in the period $425-375$ BC. ${ }^{18}$ They argue that it could have come from Selinus, like many other similar inscriptions on lead. However, they point out that the use of the 'half eta' symbol $r$ to indicate aspiration has a parallel in Himera, not Selinus. ${ }^{\text {I9 }}$

Jan Bremmer and others suggested 409 (the date of the destruction of Selinus by Carthage) as a terminus ante quem for the Getty tablet. ${ }^{20}$ We have indications that Selinus was inhabited after 409, even if many limitations to civic life were in place. ${ }^{2 \mathrm{I}}$ The terminus ante quem of 409 is not relevant if Himera is the place of origin of the text or of the tablet.

The Getty tablet contains, as many scholars have noted, a series of mistakes that originate in writing, not in composition or oral transmission. The text itself stresses the importance of writing and copying. Right at beginning, it presents itself as 'the meaning-filled letters of

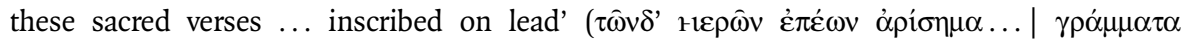

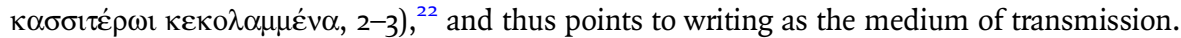

There are several mistakes in the writing of aspirations. ${ }^{23}$ Different explanations have been put forward, which require a complex series of adaptation between different linguistic contexts and/or writing systems. ${ }^{24}$ Two mistakes clearly suggest that the Getty



crucial for understanding the meaning of each artefact in context: see e.g. Battezzato (2005); Ferrari (2004) I03, (2007) II8-2I, 30, (2008) I-8, 25-6.

I6 Janko assumes separate 'archetypes', one in 'Doric dialect' and one 'in a post-Homeric form of the epic dialect', for different parts of the text (Janko (2013) 55-6).

17 See esp. lines 38-40: Janko prints the hexameters in separate lines in 2013, but as prose in 2015. See Janko (2015) 6, col. ii lines $\mathrm{I} 8-20$ and $2 \mathrm{I}-2$.

I8 Jordan and Kotansky (20II) 55 .

I9 Jordan and Kotansky (20II) 55. See also Janko (2013) 32 n. 7 and Tribulato (20I8b) I5 and n. 3I. Janko (2013) 38 n. 30 considers the possibility that the text was from Himera, and copied in Selinus. Antonetti (2018b) II4-I6 offers the most extensive and detailed discussion of the attestation of the $r$ symbol and concludes that it points to a Sicilian origin of the copy. Bremmer (2013) 28; Janko (2013) 37, (2015) 3. See e.g. Marconi (2018) I88-9. It is true that Selinus could perhaps not be described as a polis after 409 (Janko (2013) 37), but someone could have copied an earlier text: a post-409 date for the tablet still allows the text to be earlier. 
is very likely to derive from royinv: the half eta, indicating aspiration, was mistaken for an iota. ${ }^{25}$ Olga Tribulato plausibly argues that the spelling rદ́ $\pi \varepsilon$ ' (i.e. ह̌ $\pi \varepsilon(\alpha)$ 'words') in line 7 is a copying mistake originating from a written text that read Fé $\pi \varepsilon$ '. She notes that the digamma is not used in texts from fifth-century Himera or Selinus. ${ }^{26}$ It is however used in the late sixth-century lex sacra from Selinus and is attested until the mid-fifth century in that city. ${ }^{27}$ This would be consistent with the hypothesis that the Getty Hexameters derive from a text written many decades before the end of the fifth century, at a time when digamma was in use; the sign was unfamiliar to a late fifth-century scribe and was wrongly transcribed. ${ }^{28}$ We would thus need to posit an 'original' Ionic-Epic text without digamma; we must suppose that it was then transcribed in an area where the digamma was written (at least on some occasions) and the corresponding sound pronounced; and finally, we must suppose yet another transcription which mistakes the digamma (by now out of fashion, or not in use in the area) for an aspiration mark. This projects the text into a past that is very distant from the dating of the Getty tablet.

It seems likely that this text was in circulation, in some form, in the late sixth or early fifth century. This has important consequences not just for the dating of the composition but also for the relationship of the Getty Hexameters to tragedy.

\subsection{Language}

The Getty Hexameters use a mainly Ionic-Epic language, but several non-Ionic forms are also

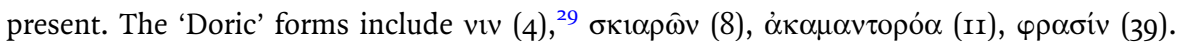

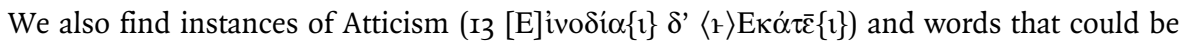
'Doric' or Attic (34 ßí 1 , dative). ${ }^{30}$

Tribulato convincingly suggests 'that the original text employed an Ionic diction mixed with certain metrically guaranteed features adopted from Doric and perhaps consciously employed to gesture towards the linguistic context in which the text was produced', and connects this with Himera, a city where, according to Thucydides (6.5.I), a dialect



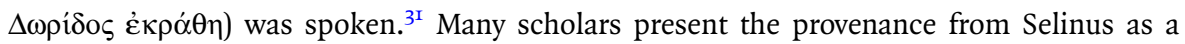
fact, but Himera, as Tribulato argued, is at least as likely as Selinus, if not more. ${ }^{32}$

25 This error is discussed by Bettarini (20I2) II2 n. 9; Janko (20I3) 48; Tribulato (20I8b) I2. Tribulato stresses that this mistake implies a written transmission of the text.

26 See Tribulato (20I8b) i6.

27 Bettarini (2005b) 63-4. See also Jameson et al. (1993) 46; Dimartino (2015) 139, I4I, I59.

28 See Tribulato (2018b) I2-I4.

29 Written $v \mu$ in the tablet, because of assimilation to the first consonant of the following word, $\pi \eta \mu \alpha v \varepsilon$ ov

30 Some of these forms can be seen not as specifically Doric but as 'common' Greek forms: see the excellent discussions by Bettarini (2012); Janko (2013) 46-56; Lundquist (2016) 440-2; Tribulato (2018b) I4-20, with further references.

Tribulato (2018b) I9. On the dialect of Himera see Tribulato (2018a). temple of Demeter. However, the connection between Hecate and Persephone is found in many Greek texts, as 
There is another passage in the Getty Hexameters which may suggest the mixing of different linguistic codes. At line 16 the tablet presents the word $\pi \rho \mu_{0} \lambda \varepsilon \varepsilon \sigma \alpha$, corrected into $\pi \rho \mu_{0} \lambda \mathrm{ov} \sigma \alpha$ in the editio princeps, a correction accepted by all subsequent editors. ${ }^{33}$ This is a very strange mistake, since -oṽ $\sigma \alpha$ is a very common participle ending, correctly transcribed

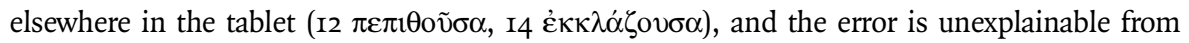
a palaeographic or phonetic point of view. One could explain it more easily if the original had the form $\pi \rho \mu_{0} \lambda \lambda_{0 i \sigma \alpha}$. This Aeolic/Pindaric participle form is common in lyric but unusual in other genres, and it could have prompted the scribe to assimilate the ending to

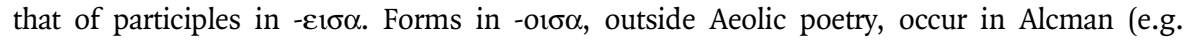

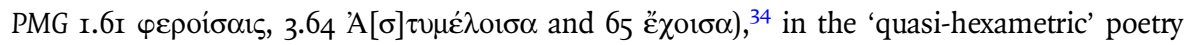

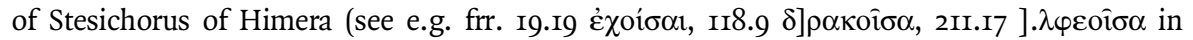
Finglass' edition), ${ }^{35}$ in Pindar and Bacchylides, ${ }^{36}$ in kitharodic poetry, ${ }^{37}$ in Eumelus (PMG

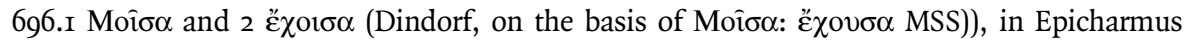


probably the form that Epicharmus used here), ${ }^{3}$ Rhinthon (fr. 6 Kassel-Austin $\check{\varepsilon}^{\prime} \chi 01 \sigma \alpha$ ). The occurrence of these forms in non-Aeolic poetry are to be explained as borrowing from the Aeolic tradition. ${ }^{39}$ The forms also occur in hexametric or elegiac epigraphical texts from many areas, including Attica (PMG 938e Moîó́ $\mu \mathrm{ol}$ ), Corinth, ${ }^{40}$ Boeotia, ${ }^{4 \mathrm{I}}$ Crete $^{42}$ and Southern Italy. ${ }^{43}$ These instances in hexametric or elegiac poetry are probably to be interpreted as influenced by the language of lyric poetry. Form in -oi $\alpha \alpha$ are of course regularly found in the Theocritean corpus (e.g. $20.39 \mu$ o felt as part of the 'Doric' (Pindaric) elements. ${ }^{44}$ Greek poetical languages regularly insert elements from different traditions into whatever literary language they adopt as primary. ${ }^{45}$

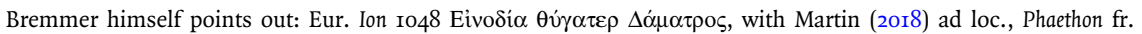

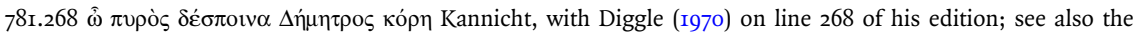
Homeric Hymn to Demeter 5I-89, with Richardson (1974) ad loc.

Tribulato (2018b) I4 considers this one of the 'mistakes concerning vowels which however are purely accidental'. See Hinge (2006) $43^{-6}$. See Willi (2008) 68; Finglass in Finglass and Davies (2014) 44. Many instances in Pindar: see e.g. Pyth. 8.4 and 9.32 है $\chi 01 \sigma \alpha$. For Bacchylides see 19.13-I4 Snell-Maehler $\lambda \alpha \chi 0 \hat{\sigma} \sigma \alpha v$ (the forms in -ov $\alpha$ are normal: see Maehler (2004) 12). Cassio (2005) 22-3, 34-8. See Cassio (2005) and the lists and discussions in Favi (2019) I67-7I; Wachter (200I) 340-I.

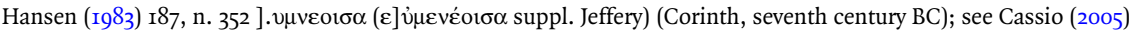
24. Probably hexametrical.

4I Prauscello (2019) 75-8 discusses an example found in CEG II4.4, an epigram in elegiacs from Kopai, Boeotia, dated to the first half of the fifth century BC.

42 Tribulato in Willi (2019) 86 quotes an epigram from Polyrrhenia, Crete, dated to the second/first century BC (SEG I6, 532).

43 Favi (2019) I67 n. 75 discusses Moıбôv, an instance found in a vase from Satùro, near Tarentum.

44 On these forms see Hunter (1999) 26, with further references.

45 See in general Cassio (2016). 
This does not mean that the model of the Greek Hexameters was originally written (if an 'original' model ever existed) with the form in -or $\sigma \alpha$ or that we should expect these forms to occur consistently in the poem. It simply means that at some point in time one occurrence of the participle was given this unique non-standard feature, which could have been perceived as a prestigious 'Lyric'/'Doric'/'Stesichorean' element. That unique form was then corrupted to $\pi \rho \mu_{0} \lambda \varepsilon 1 \sigma \alpha$.

2.4 Conclusions on date and place of origin

On the basis of these palaeographic and linguistic considerations, it is very likely that the tablet itself was written in Sicily (possibly in Himera or Selinus) at the end of the fifth or beginning of the fourth century BC. The text itself (or at least large sections of it) must have been composed some decades before it was inscribed on the Getty lead tablet; it was transmitted in writing, probably in different Greek-speaking contexts and using different alphabetic systems.

\section{Structure of the text}

The Getty Hexameters are structured according to a very clear pattern. We find four occurrences (with slight variations) of a line invoking Paean. These invocations divide the text into clearly marked sections which differ for content and style. This is the outline:

I-5 the speaker asserts the efficacious power of the incantation

6 invocation to Paean:

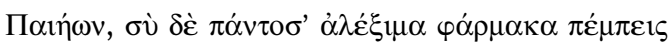

'Paeon - to every place you send protective drugs - '

7-22 Paean narrates a story about a goad, related to Persephone and Hecate

23 invocation to Paean:

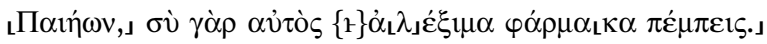

'[Paeon] - you send protective drugs yourself - '

24-3I the text states that incantations will protect ships, people, animals and the city in general

32 invocation to Paean:

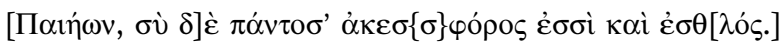

'[Paeon] - to every place you bring cures and are good.' 
33-48 Ephesia grammata

49 invocation to Paean:

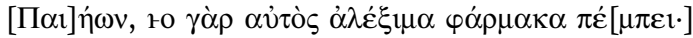

'[Paeon] - since he sends send protective drugs himself -' conclusion: Paean will protect against evil pharmaka.

Refrains are of course common in magical texts (e.g. Aesch. Eum. 328-32=34I-6; Theocritus 2.I7), but also in paeans. ${ }^{46}$

Interpretations of the Getty Hexameters vary. Jordan and Kotanksy consider them the 'traditional legomena of a rite of initiation into the worship of Demeter and Core'.47 Similarly, Dirk Obbink thinks that this text is 'poetry performed in a mystery context' and calls it a 'telestic song'. ${ }^{48}$ William Furley argues that 'the Getty narrative is nothing other than the sacred narrative of Dionysos' birth', and that its author is 'an Orpheotelestēs' who 'appeals to Apollo Paian as the divine healer, who, according to myth, had even saved Dionysos as a child'; ${ }^{49}$ the first line 'introduces the hieros logos of mystery rites' ${ }^{50}$ Janko instead considers it 'a late fifth-century hexametric incantation against witchcraft, into which an earlier spell is embedded; it was intended for civic rather than private use' $;^{5}$ Christopher Faraone and Radcliffe Edmonds also argue that the text is a civic incantation. ${ }^{52}$

Explicit references to mystery cult are not present in the extant part of the text, and the references to Persephone (8) and to the Idean Dactyl Damnameneus (4I) do not necessarily prove that this was used in a mystery context. The emphasis on the protection of the polis $(25-3 \mathrm{I})$ indicates that this a text was part of a ritual aimed not at a single individual but at the community as a whole. ${ }^{53}$

Ian Rutherford, focusing on the paeanic features, suggests that the Getty Hexameters can be 'a paean-incantation, in fact the only example of this sub-genre to survive'. ${ }^{4}$ One should

46 See Käppel (I992) 66-7; Rutherford (200I) 2I, 69-72 and passim; Finglass (2018) on Soph. OT I53-5.

47 Jordan and Kotansky (20II) 54.

48 Obbink (2013) I75 and 8.

49 Furley (2019) 52.

50 Furley (2019) 58.

5 I Janko (2015) I.

52 Faraone (2013) and Edmonds (2013). Faraone also suggests that the Getty Hexameters could be a sort of anthology, with rubrics marked by the Paean invocation. The focus of this article is not on whether this was 'an anthology' to begin with, but on whether the person who composed the text as we have it meant it to be used in ritual. As showed above (section 2), it is unlikely that the person who composed the text was also the person who inscribed it onto the Getty tablet. For arguments against the hypothesis that the tablet is connected with mystery cults see Edmonds (2013). Rutherford (2013) $167-8$. He also explores other possibilities: 'a hexametric ritual text' or an early instance of Kreuzung der Gattungen 'between the genres of ritual historiola and incantation paean, resulting in something that would have been recognized as a hybrid'. 
add that the dactylic rhythm is very frequent in paeans. ${ }^{55}$ Richard Janko and Carlo Martino Lucarini accept that this text is a paean in hexameters, comparable to the one composed by Socrates before his death. ${ }^{56}$ The hypothesis that this text was felt to be a Paean-incantation is compatible with its status as amulet: the first three lines of the text allude both to the oral performance of the text ( $\mathrm{GH}$ I $\dot{\varepsilon} \pi \alpha \varepsilon i \delta \omega$ 'I sing') and to the fact that the text is written down

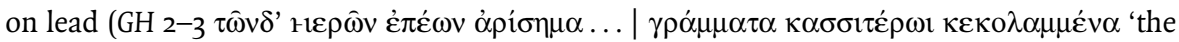
meaning-filled letters graved on lead').

The structure and language of the Getty Hexameters is reflected in some passages of Greek tragedy, especially Aeschylus. This suggests that similar Paean-incantations were more widely used and known. Aeschylus, Sophocles and Euripides all use the language of magic and incantation as preserved in the Getty Hexameters. It is certainly possible in principle that the influence went both ways, and that magical texts occasionally imitated specific tragic phrases and epithets. The interaction of genres is however in the other direction: tragedy clearly alludes to the genre of magic/religious poetry in many passages; ${ }^{57}$ magic texts do not need an allusion to the tragic genre for their literary and performative goals.

In what follows, to indicate an allusion to a genre or a sub-genre such as 'incantations' or 'paean' (as opposed to the instantiation of the genre in a specific text), we will speak of 'genre intimation'. To indicate the use of language that evokes a specific genre, we will talk of 'linguistic intimation'. To indicate an allusion to a specific text, identified by allusion to its wording, we will speak of 'textual allusion'; the text alluded to will be called the 'exemplarmodel' ('modello-esemplare' in Conte's influential terminology); 'intertextuality' will be used as a general term indicating all different kinds of relationship between texts (allusion, intimation, quotation, similarity)..$^{8}$

\section{Sophocles fr. 535 (Rhizotomoi)}

Bremmer notes that lines $\mathrm{I} 2-\mathrm{I} 3$

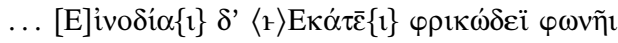

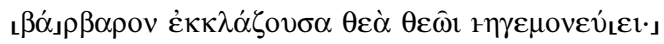

55 See below, n. 85 .

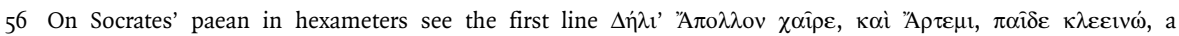
hexameter, reported by Diogenes Laertius $2.42=$ Käppel (I992) 395 (Paian 52) (Käppel states, without argument, that the text is a forgery), and Janko (2015) I and Lucarini (20I8) 33. Faraone (20II) 224-5 interprets Socrates' paean as $4 \mathrm{da}$ followed by a run of dactyls. It is impossible to disprove this, as we do not have the rest of the poem, but ancient authors normally quoted the first line of a poem to identify it; Diogenes Laertius could easily have stopped at 'A $\_\varepsilon \mu$ if that was the end of the first line, or quoted more words if the line was longer. Furley (2019) 52 claims that 'the appeal to Paieon by no means makes the Getty text a paean, as Rutherford has argued in FO [= Rutherford (2013)]; rather, this is "Orphic" Apollo, the magical healer, who also plays a conspicuous role in the later Greek magical papyri'. The hypothetical ritual role of Apollo in a Dionysiac or Orphic context does not however rule the possibility that the text is a paean: it would simply make it a paean performed in a different context.

57 See above, n. 8.

$5^{8}$ See Conte (I986) 3I; Hinds (I998) 4I-2; Morrison (2020) I8-2I, with further references. 
Hecate of the crossroads, screaming obscurely

In hair-raising voice, a goddess, leads the god

present similarities with Sophocles' fr. 535, a choral passage from the play Rhizotomoi 'Rootcutters' ${ }^{59}$ The play included a description of Medea's magic abilities. ${ }^{60}$ The fragment runs as follows:

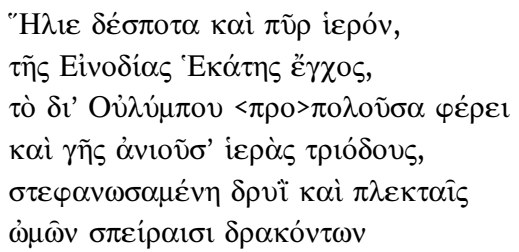

O Sun our lord and sacred fire, the spear of Hecate of the roads, which she carries as she attends her mistress in the sky and as she goes up the sacred crossroads of the earth, crowned with oak-leaves and the woven coils of savage dragons! ${ }^{6 \mathrm{r}}$

The similarities consist in the phrase 'Hecate of the roads', in the mention of torches ('spear') and the procession. It is unlikely that the widely attested epithet of the goddess was invented by Sophocles in this fragment. ${ }^{62}$ Sophocles is likely to have imitated cultic language ('linguistic intimation'); he clearly introduces an innovative metaphor ('spear') to describe a cultic object ('torch'), but the metaphor is not present in the Getty Hexameters. Many texts connect torches with Hecate and mention her role as 'attendant' and the procession. ${ }^{6}$ These considerations do not prove that the Getty Hexameters imitate the passage of Sophocles. Nor could one argue in the opposite direction. As one anonymous reader put it, 'in a world where it is entirely plausible that there were processions in connection with Hecate of the crossroads, no link at a textual level is

59 See Bremmer (2013) 28 and Janko (2013) 50 ('this is as striking as the parallel with Euripides' Hecuba').

6o See Lloyd-Jones (I996) 268-9; Radt (1999) 410.

6I Text and translation from Lloyd-Jones (1996), adapted: I capitalised the epithet Eivooí $\alpha \varsigma$ in the Greek text and

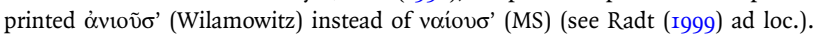

62 For other occurrences of this epithet for Hecate see Johnston (I990) 23-4, 7; Zografou (2010) 109-22; below, n. 75 ;



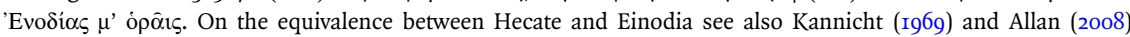
ad loc., who also lists passages where Hecate is said to carry torches: Ar. Thesm. 858, with Austin and Olson (2004) ad loc. (the most exhaustive collection of evidence), Lys. 443. In Soph. Ant. IIg9 the 'Einodia goddess' (epithet only) is coupled with Pluto: this is probably a reference to Hecate (so e.g. Griffith (I999) ad loc.), but it may also refer to Persephone, often linked to or equated with Hecate: see Martin (2018) on Eur. Ion I048

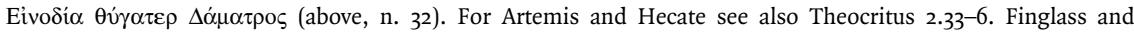
Davies (2014) 502 on F 178 Finglass offer a very useful survey of the evidence.

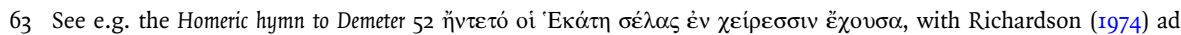
loc.; Ar. Ran. I36I-2. 
required'. It is legitimate to see 'linguistic intimation' to cultic language in Sophocles, but not a 'textual allusion' by Sophocles to the Getty Hexameters or vice versa.

\section{The Oresteia of Aeschylus}

The Oresteia provides some striking parallels for the language and genre of the Getty Hexameters ('linguistic intimation' of magic language in tragedy). Incantations and magic are often discussed in the trilogy, at crucial moments: in the Agamemnon the most striking passages occur in the third stasimon, in Clytemnestra's speech to Agamemnon (958-72), and in Thyestes' curse, as reported by Aegisthus (I6oI-2); in the Choephori, in the second stasimon; in the Eumenides, in the incantation of the Furies in the first stasimon. ${ }^{64}$ This section will show that the connection between the Oresteia and magic texts, in particular the Getty Hexameters, is stronger than simple linguistic intimation.

\subsection{The Agamemnon}

Let us start with the parodos of the Agamemnon. The chorus, just like the speaker of the Getty

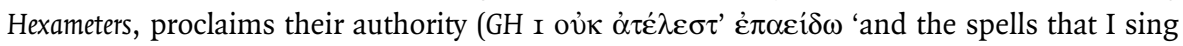

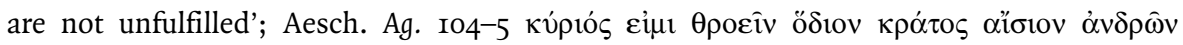
$\dot{\varepsilon} v \tau \varepsilon \lambda \dot{\varepsilon} \omega \mathrm{v}$. 'I have authority to tell of the auspicious departure of the commanders, | men invested with power-'). ${ }^{65}$ The chorus here speaks in hexameters, suggesting a link with the epic and kitharodic tradition; ${ }^{66}$ the Getty Hexameters form part of this tradition too.

There are similarities in content. The Getty Hexameters envisage a crisis situation: 'a doom that brings death' (26-7) threatens humans and flocks; the crisis can be meet by repeating 'night and day' (29) a prayer or incantation, saying '[better] so for the city' (3I); the sequence ends with an invocation to Paean at 32 . This is the text (23-32):



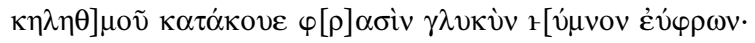

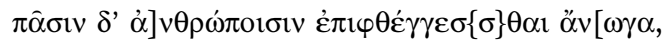

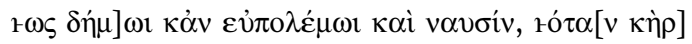

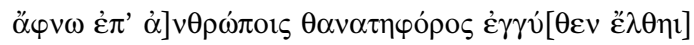

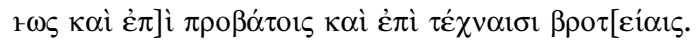

\footnotetext{
64 See Faraone (I985); Garvie (I986) on Cho. 819-24; Griffith (I995) ior n. 26; McClure (I996), (I999) 8o-92; Curti (2012); Medda (2017) on Ag. 360-I ( $\pi \alpha v \alpha \lambda \omega ́ \tau o v$, attested in magical papyri), 699-70o ( $\tau \varepsilon \lambda \varepsilon \sigma \sigma i \varphi \rho \omega v$, attested in

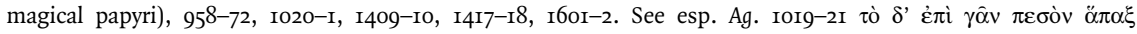

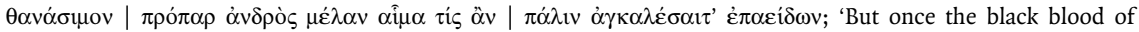
death | has fallen on the earth in front of a man, | who by any incantation can summon it back again?' (tr. Sommerstein (2008)); cf. Eum. 649.

65 Translation from Sommerstein (2008).

66 Cf. Raeburn and Thomas (20II) on Aesch. Ag. I04-59; Medda (2017) I.47-9 and II.71, 77-8, including the linguistic and metrical comment on Ag. I04-5 (epic influence); Fraenkel (I9I8) 32I-3 = (I964) I.202-3; D'Alessio (2009) I42-3 (kitharodic influence).
} 


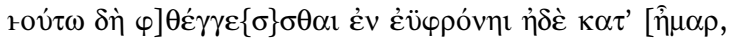

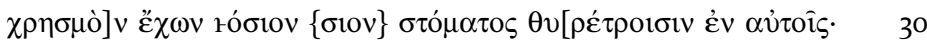

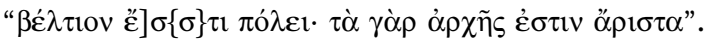



[Paeon] - you send protecting drugs yourself -

[Kindly] hear in your mind the incantation's sweet song.

[I bid you] intone [it] for [all of the] people,

As in [folk] good at war and in ships, when [some doom]

[Comes suddenly] nigh bringing men to their deaths,

[As too both] for flocks and for mortal men's crafts,

Utter [what follows] by night and by day,

Keeping holy your [oracle in] the doors of your mouth:

'[Better] so for the city: for order is best.'

[Paeon] - to every place you bring cures and are good.

Many supplements are uncertain, but the general sense seem to be well captured by Janko's text as presented above. An important point for the following discussion is the text of GH $3 \mathrm{I}$. Different supplements can be proposed. Kotansky suggests $\left[\chi \rho \eta \dot{\sigma} \sigma \mu \alpha \gamma^{\prime} \varepsilon \dot{\varepsilon}\right] \sigma \tau t \pi \dot{\partial} \lambda \varepsilon 1$ and

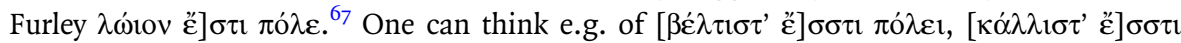

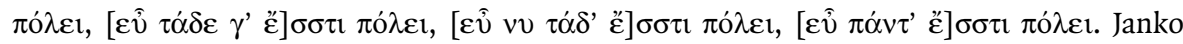
is in any case probably right to suppose that $\mathrm{GH}$ 3I is a direct speech, which must be 'spoken night and day' (29) by human beings who must pronounce or keep something 'holy' in their 'mouth' (30). Janko provides some modern comparisons for this type of repeated statement, ${ }^{68}$ but we will see that the Oresteia offers ancient parallels.

In the parodos of the Agamemnon we find again a crisis that threatens the survival of the community (in this case, the army) that is at war (cf. GH $26 \delta \eta \dot{\eta} \mu \omega t \kappa \alpha \dot{v} v \varepsilon \dot{v} \pi \mathrm{o} \lambda \dot{\varepsilon} \mu \omega t$ : the text is uncertain but the mention of war is not). The army suffers from hunger (Ag. 188, 194), and

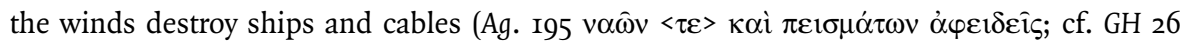
vovoiv). This crisis is announced earlier in the parodos, when the chorus mentions the omen (the pregnant hare killed by the two eagles: Ag. 109-20) and intones the famous refrain $($ Ag. $\mathrm{I} 2 \mathrm{I}=\mathrm{I} 39=\mathrm{I} 59)$ :

67 See Kotansky (2016) and Furley (2019) 6o.

68 Janko (2013) 35. Lucarini (2018) 28 rightly asks for ancient parallels. Lucarini (2018) $27-8$ suggests that the object of $\varphi \theta \varepsilon ́ \gamma \gamma \varepsilon \sigma \theta \alpha \mathrm{l}$ in $\mathrm{GH} 29$ is lost in the preceding lacuna and that we should read (note the quotation marks in the Greek text printed by Lucarini): ["П where we would expect a metrically impossible accusative; the insertion of quotation marks is unhelpful for a text that was meant to performed orally, and Lucarini fails to indicate parallels for this syntax (a single word in

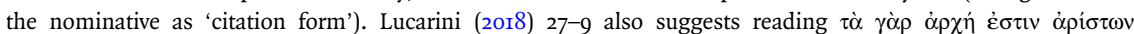
'queste cose infatti sono principio di cose ottime' at the end of $\mathrm{GH}$ 3r but a conjecture introducing the hiatus $\dot{\alpha} \rho \chi \eta \dot{~} \dot{\sigma} \tau \iota v$ (without the common epic shortening of eta) is not especially likely. 


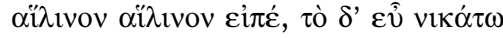

Cry sorrow, sorrow, but may good prevail! ${ }^{69}$

This refrain again recalls the hexameter (five dactyls, with the first eight syllables corresponding to the first part of the hexameter until the 'feminine' caesura in the third foot). The refrain thus frames, as in the Getty Hexameters, narrative sections that contain both the description of evils threatening a community, and possible remedies. The text also recalls $\mathrm{GH} 3^{\mathrm{I}}[\beta \varepsilon \dot{\varepsilon} \lambda \tau \imath \mathrm{\nu}$ है] $\sigma\{\sigma\} \tau$ $\pi$ ónel '[better] so for the city'. In fact, in the first section the prophet Calchas explains that



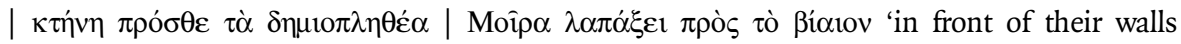
| Destiny will violently plunder | all the mass of livestock the community possesses'). The

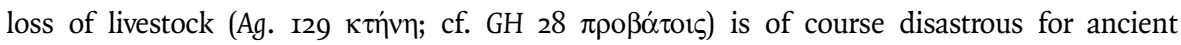
societies, and we will see it mentioned again in the Oedipus Tyrannus (see below, section 6), in a context that also recalls the invocation to Paean of the Getty Hexameters. The prophet explains that the expedition on Troy is at risk because of the wrath of Artemis, a threat of famine and destruction to the Greek community (Ag. I34-7, I94). After the second occurrence of the refrain (I39), the speech of the prophet resumes. Note that the Getty Hexameters too are structured as one or possibly two direct speeches of Paean, interrupted by addresses to Paean himself (above, section 3). The refrain 'may good prevail!' is a protective charm (repeated three times) for the Greek army, and the prophet stresses that the divinity that might help is Paean himself (Ag. I47-5I), again in a passage that recalls the hexameter (seven dactyls in lines $148-9$ and $150-\mathrm{I}$ ): ${ }^{70}$



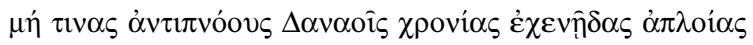



I47

I48-9

I50-I

So I call on the healer Paean:

Let her not cause any persistent adverse winds that hold back the Danaan ships From sailing, bent on another sacrificial slaughter, one without music of feasting.

The phrase of line 147 follows a pattern that we find in lines C-D of the Phalasarna tablet (one of the magical texts that partly overlap with the Getty Hexameters): ${ }^{71}$

69 Here and below, text and translation of the Oresteia are taken from Sommerstein (2008), with occasional adaptations. The commentaries by Fraenkel (1950), Denniston and Page (1957) and Medda (2017) offer detailed discussion of the textual and interpretive problems of these passages, with ample bibliography. It is impossible to discuss these problems here. On embedded speeches in the parodos of the Agamemnon see the perceptive remarks of Uhlig (2019), who stresses how the choral voice blends with that of Calchas in the second and third repetition of the ritual refrain.

70 The metre is: iamb choriamb baccheus || 7dactyls | 7dactyls |. See West (I99ob) 483; Medda (2017) I.388, II.73. On protective magic see Edmonds (2019) Ir6-48, esp. I43-4 on the Getty Hexameters.

$7 \mathrm{I}$ See Jordan (1992) I94, whose text and translation I print. For the overlap see GH 33-42, and Janko (2015). 


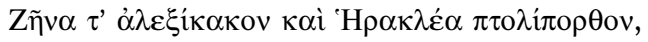

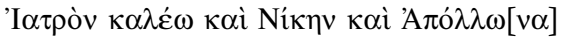

I call on Zeus the averter of ills, Herakles the sacker of cities, Iatros, Nike, Apollon.

The pattern ' $I$ call on $X$ ' is often attested as a formula of invocation in classical Greek literature. ${ }^{72}$ It clearly recalls the cultic setting that we find in the Phalasarna tablet.

Calchas echoes incantatory and magical language ('linguistic intimation'); but his invocation fails to avert disaster completely. The Danaan ships do manage to sail, after

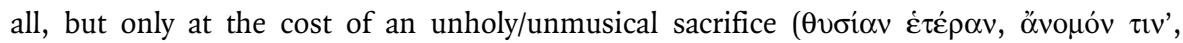



Both the Getty Hexameters and the prophet in the Agamemnon call on Paean to save the community from a crisis; and in both cases the crisis involves Hecate/Artemis. The goddess that is threatening the Greek community in the Agamemnon is Artemis and she is identified with Hecate in a probable interpretation. Alan Sommerstein and Enrico Medda print the text transmitted by the manuscripts TF (Ag. I40-I): ${ }^{73}$

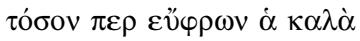

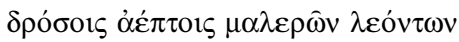

So very kindly disposed is the Fair One

To the unfledged seed of fiery lions.

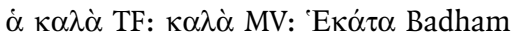

Martin West prints Charles Badham's bold (and attractive) conjecture 'so very kindly disposed is Hecate'. ${ }^{74}$ Even scholars who do not print the correction accept that plausibility of the connection between Artemis and Hecate here. ${ }^{75}$ Aeschylus (Supp. 677) and Euripides (Pho. I09-Io) gave Artemis the epithet Hecate. ${ }^{76}$ Already Stesichorus identified Iphigenia with Hecate (F I78 Finglass). The Catalogue of Women from the

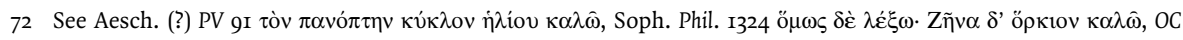

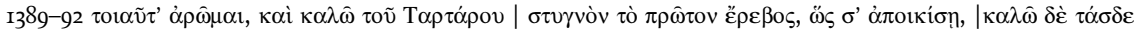

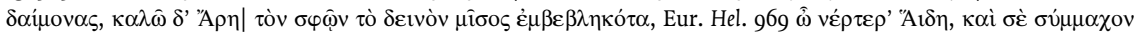

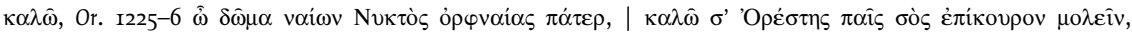

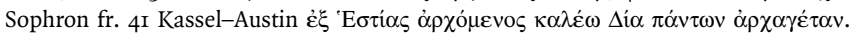

73 See Sommerstein (2008) and Medda (2017) ad loc.

74 See West (1990b) ad loc. and (r99oa) i77-8.

75 See Medda (2017) ad loc. See also Friis Johansen and Whittle (I980) on Aesch. Supp. 676; Mastronarde (I994) on Eur. Pho. 109-10. These commentators quote fifth-century epigraphic evidence for the epithet 'Artemis Hecate' (e. g. IG xIII.8.359, from Thasos). As one of the readers points out, however, arguing against Badham's conjecture, 'the specific context here is relation to young animals/humans, and this is much more Artemis' concern than Hecate's'.

76 On the many connections between Hecate and Iphigenia, Hecate and Artemis, Artemis and Iphigeneia see the excellent and detailed discussion in Finglass and Davies (2014) on F I78 Finglass. 
Hesiodic corpus calls Agamemnon's daughter 'Iphimede' and states that after her sacrifice she was made immortal and transformed into Artemis 'of the roads' (an epithet that is typical of Hecate: see above, section 4). ${ }^{77}$ The connections between Hecate and the sacrifice of Iphigenia are very strong.

In the Agamemnon we thus find Hecate and Paean, as well as a refrain that imitates the auspice of GH 3I '[better] so for the city': the chorus of the Agamemnon, in the context of

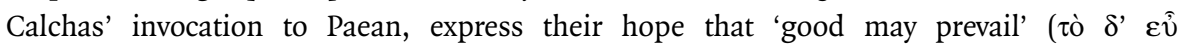
vıкó $\tau \omega)$. The refrain is taken up again by Agamemnon himself later in the parodos. The monologue in which he expresses his decision to sacrifice his daughter ends with the

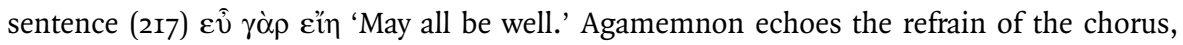
but the wish that 'good may prevail' is shown to be obviously void at this moment of crisis (202-4). This echo retrospectively calls into question the efficacy of Calchas' initial appeal to Paean. The chorus voice their disapproval of Agamemnon's decision in the strongest possible terms (218-27). Not only that: the sacrifice of Iphigenia substitutes and represses the Paean that the prophet invoked at I47. Agamemnon, in a situation that

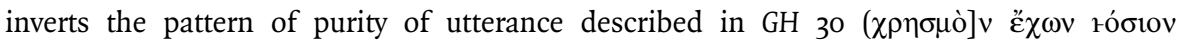

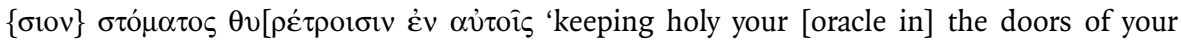



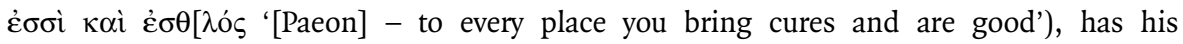
helpers gag his daughter, who used to sing a paean in her house. Compare Ag. 235-7:



$\varphi \nu \lambda \alpha \kappa \hat{\alpha} 1 \kappa \alpha \tau \alpha \sigma \chi \varepsilon \hat{\imath} v$

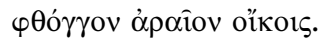

And by putting a guard

On her fair face and lips to restrain

Speech that might lay a curse on his house.

Iphigenia is threatening to issue a 'curse' from her 'mouth', the very opposite of the 'pure' oracle that the 'mouth' mentioned in GH 30 must observe. The chorus then explicitly comment on the fact that Iphigenia used to sing a paean in her father's halls (Ag. 243-7):



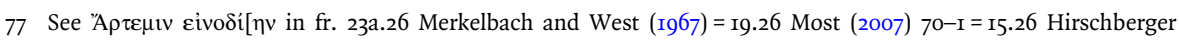
(2004) 96, 2I3-I4, with Hirschberger's comments ad loc. 


\section{Because often}

At the rich banquets in her father's dining-chambers

She had sung, a pure virgin with pure voice,

Duly and lovingly performing her father's

paean for good fortune to accompany the third libation.

Iphigenia's suppressed paean thus substitutes Calchas' invocation to Paean at I47: Paean is evoked by the prophet but not sung and remains inefficacious. The chorus does not sing a paean but a refrain to avert evils - but they strongly condemn as evil the sacrifice. Agamemnon echoes the refrain of the chorus when he decides to sacrifice his daughter.

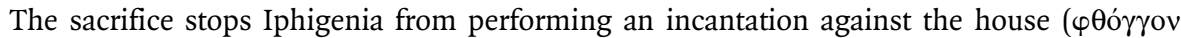

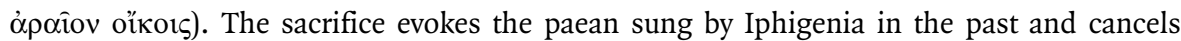
the possibility of a paean by her. This sacrifice suggests the impossibility of singing a paean and of averting evil in the circumstances.

The Getty Hexameters offer ritual and linguistic parallels: the refrain invoking Paean as an incantation against evil $(6,23,32,49)$, the purity of the tongue (30) and the wish that 'this is better for the city' (3I; cf. Ag. I2I = I39 = I59 'may good prevail', 217 'may all be well'). The parodos is thus structured as an incantation that succeeds and fails at the same time: it manages to solve the crisis caused by adverse weather conditions but fails to achieve the prevalence of good that its incantatory refrain was aiming to achieve. The allusion to rituals for Paean and Hecate will not bring 'good' to Agamemnon: his echo of Calchas' prayer is a self-defeating one.

It is impossible to indicate textual signs that prove a direct allusion in the text of the Agamemnon to a specific passage in the Getty Hexameters ('textual allusion'). However, the linguistic, structural and cultic similarities (refrains, appeal to Paean, curses, Hecate/ Artemis) suggest not simply a 'genre intimation' and 'linguistic intimation' but also an allusion to a magic text that had a very similar structure to the Getty Hexameters.

\subsection{The Choephori}

The chorus of the second play of the trilogy take up that wish, in another passage that explicitly mentions magic and the welfare of city. In the second stasimon, the chorus imagine that Hermes will help Orestes kill Aegisthus and Clytemnestra and become king of Argos. This is what the chorus imagine they will do after Orestes' victory (Cho. 819-26)

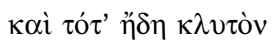

$\delta \omega \mu \alpha \dot{\tau} \tau \omega \nu \lambda v \tau \eta \dot{p i o v}$

820

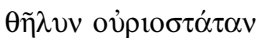

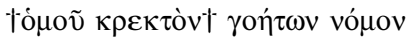

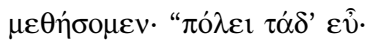

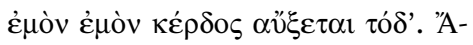

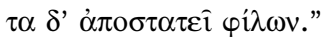


And then at last, for the voyage

That will set the house free,

We will utter feminine strains to set the wind fair, the strains that are sung

By charmers to <shrill> accompaniment: 'it is good for the city!

My gain, my gain is swelling here,

And destruction stands far from my friends.' (text and translation Sommerstein (2008), adapted $)^{78}$

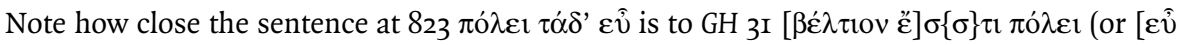
$\pi \alpha \dot{v} \tau \tau^{\prime}$ '̌ $] \sigma \sigma \tau \imath \pi$ ó $\lambda \varepsilon \imath$ or other similar supplements). ${ }^{79}$ The chorus is explicitly saying that the words they are going to pronounce are those of 'charmers', 'magicians', people who make

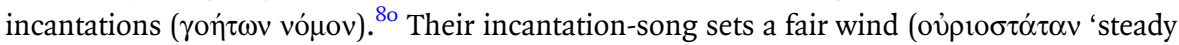
and prosperous'; cf. oüpros 'with a fair wind'), i.e. the goal of the invocation to Paean in the parodos of the Agamemnon: the fair wind is produced by means of an incantation, as indeed in Empedocles and other magical rituals. ${ }^{8 \mathrm{I}}$ This appears to be a direct echo of the incantation language attested in the Getty Hexameters. We have an explicit reference (not an 'intimation' or allusion) to the language and words used by 'magicians', 'charmers', and, at that very moment, a sentence that is very close in wording and content to a sentence found in the Getty Hexameters. This is as close to a textual allusion as it gets; of course, it is possible that the sentence used in the Getty Hexameters (the 'exemplar-model') was also used in other, unknown, magic texts, and that the allusion is not to this specific text.

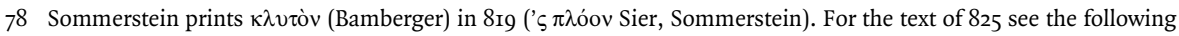
note.

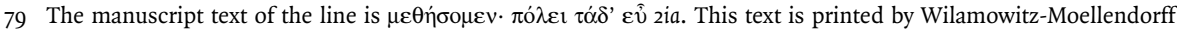
(1914) and Page (1972); it requires the addition of a syllable in the corresponding line of the antistrophe: 835

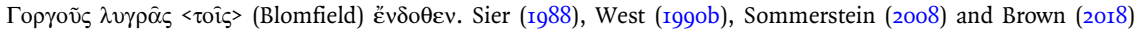
leave the antistrophe unchanged and print Kirchhoff's conjecture $\pi \lambda \varepsilon \hat{\imath}$ in the strophe, which yields $\mu \varepsilon \theta \dot{\eta} \sigma o \mu \varepsilon v$.

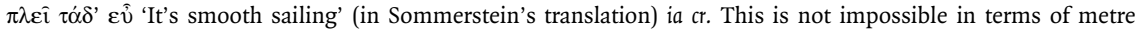
and language/imagery, but the MS reading's emphasis on the polis is welcome: see 302, 43I and esp. 864,

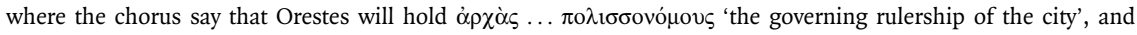

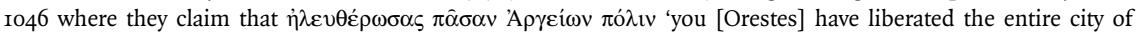
Argos'. Objections against the addition of toîs in 835 are weak. Garvie (1986) on Cho. 833-6 claims that 'the Medusa story applies essentially to Clytaemnestra, and the point is weakened by the generalising plural, if at any rate it includes Aegisthus'. However, the plural may well refer to Clytemnestra alone, as in $4 \mathrm{I} 9$ $\tau \hat{\omega} \mathrm{v}$ $\tau \varepsilon \kappa о \mu \varepsilon ́ v \omega v$ (lit. 'parents'), and in its vagueness softens a direct mention of matricide. For generic plurals, in reference to a single individual, see Garvie (1986) on Cho. 5I-4, 215, 382-5, 4I8-I9, 689.


'wailer' (see e.g. Page (1972): 'aegre iubilantibus congruit'). It is not clear why Garvie (1986) ad loc. claims that a 'melody of sorcerers' does not carry conviction. yoń $\tau \omega v$ is printed, among others, by WilamowitzMoellendorff (1914) and West (I9gob). Mention of charmers is perfectly appropriate in a wish for the future, and especially so in connection with $\lambda v \tau$ inprov: see Burkert (1962) 50 n. $7 \mathrm{I}=(2006)$ 185 n. 72; Sier (1988); Brown (2018) ad loc.

8I On winds and magic see Od. I0.19-27, Empedocles 3I A I DK = PI6 in Laks and Most (2016) 340-I = Diog. Laert. 8.6o, Empedocles 3I B III.3-5 DK = D43.3-5 in Laks and Most (2016) 388-9; Kingsley (I995) 217-32; Faraone (I999) 39; Collins (2008) 57 . 
The chorus of the Choephori contains another striking echo of the language ('linguistic intimation') of the Getty Hexameters. During the lament for Agamemnon, the chorus express the following wish (Cho. $368-7 \mathrm{r})$ :

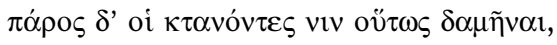
$<\mathrm{x} \rightarrow \theta \alpha v \alpha \tau \eta \varphi o ́ p o v \alpha \hat{i} \sigma \alpha v$

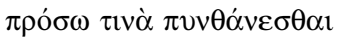

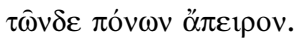

But rather should his killers have been slain so,

$<$ So that $>$ someone far away

Would have learned of their deadly fate

Without experiencing these present troubles ...

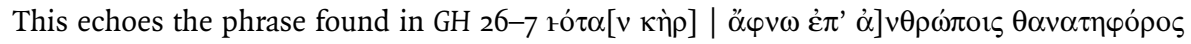
$\dot{\varepsilon} \gamma \gamma \dot{v}[\theta \varepsilon v$ É $\lambda \theta \eta 1]$ 'when [some doom] | [comes suddenly] nigh bringing men to their deaths'. ки́ is a virtually certain supplement by Burkert (no other suitable word would fill the lacuna so well). ${ }^{82}$ As we will see (below, sections 6 and 7), the adjective $\theta \alpha v \alpha \tau \eta \varphi$ ópos is very rare in classical, especially poetic, texts: it occurs in a series of passages that seem to allude to the same context as the Getty Hexameters. Another passage in the Choephori that recalls the language of the Getty Hexameters occurs in the first stasimon. The Getty Hexameters state that, thanks to their incantatory powers (GH 4-5),

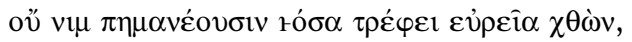



No creature that the broad earth rears shall cause him harm, No creature in the sea that roaring Amphitrite feeds at sea.

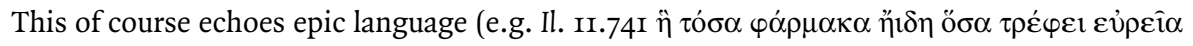

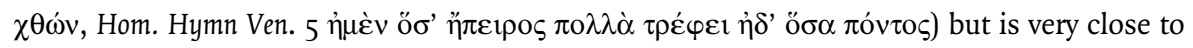
Cho. 585-92:

$\pi \mathrm{o} \lambda \lambda \grave{\alpha} \mu \grave{\varepsilon} v \gamma \hat{\alpha} \tau \rho \varepsilon \dot{\varepsilon} \varphi \varepsilon \mathrm{l}$

$\delta \varepsilon v v \grave{\alpha} \delta \varepsilon \mu \alpha \dot{\alpha} \tau \omega v$ ö $\chi \eta$.

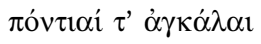

$\kappa v \omega \delta \dot{\alpha} \lambda \omega v \dot{\alpha} v \tau \alpha \alpha i \omega v$

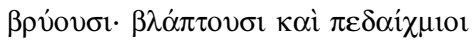

82 The supplement is strengthened by comparison with the scholion 8.70a in Erbse (1969-88), which glosses the dúo


Moirai that bring death' (the scholion then refers to Aeschylus' Psychostasia: see Taplin (1977) 43I-3; West (2000) $345-7=(2013)$ 347-50; Radt (2009) 375; Davies (2016) 25-3I, with further references to modern discussions). 
$\lambda \alpha \mu \pi \alpha ́ \delta \varepsilon \varsigma \pi \varepsilon \delta \alpha \dot{\alpha} \rho \circ o 1$,

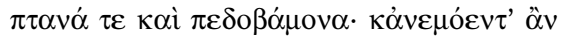

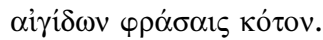

The earth breeds many beings

That cause terrible, fearful suffering,

And the bosom of the deep

Teems with hostile monsters;

Torches flaming on high,

Between sky and earth, do injury

To winged and footed creatures, and one might also speak

Of the windy wrath of hurricanes.

Note also the chorus' mention of 'torches flaming on high' (590 $\lambda \alpha \mu \pi \alpha \dot{\delta} \delta \varepsilon \varsigma \pi \varepsilon \delta$ '́opor; cf. GH I3 $[\lambda] \alpha \mu \pi \alpha \dot{\delta} \alpha \varsigma$, Hecate's torches), and the similarity between 59I $\pi \varepsilon \delta$ o $\beta \alpha{ }^{\prime} \mu v_{\alpha} \alpha$ 'footed creatures' and GH io $\tau \varepsilon \tau \rho \alpha \beta$ ' $\mu$ ov $\alpha$ (the 'four-footed' goat lead by the mysterious 'child').

These parallels show the pervasive presence of incantatory language ('linguistic intimation') in the Oresteia.

\section{$5 \cdot 3$ Incantatory language and the Oresteia}

These parallels do not prove that the parodos of Agamemnon alludes to the Getty Hexameters specifically ('textual allusion'). They however suggest that the Oresteia alludes ('linguistic intimation') to some phrases from this magical tradition, and to the ritual practices that

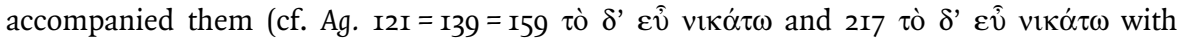





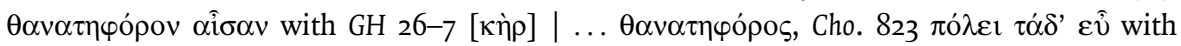

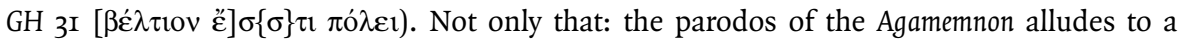
magical/ritual text with paeanic refrains (in the tradition of the Getty Hexameters) ('genre intimation'). In the Agamemnon, however, this paeanic incantation/prayer fails and is substituted by a sacrifice (in which the paean is suppressed). The Choephori specifically


allude to a phrase of that is present in the Getty Hexameters (possibly a 'textual allusion'). The tradition of incantation that was found in the Getty Hexameters thus allows us to see the poetic and magic-religious background of some crucial moments in the trilogy, and the actual use in incantatory texts of the language employed by Aeschylus.

\section{The Oedipus Tyrannus of Sophocles}

Another striking similarity with the Getty Hexameters is found in the Oedipus Tyrannus of Sophocles. The prologue explained that 'the city [...] is grievously tossed by storms'






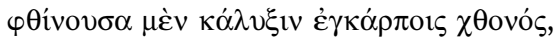

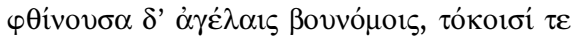

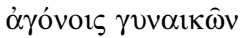

a blight is on the buds that enclose the fruit, a blight is on the flocks of grazing cattle and on the women giving birth, killing their offspring.

In the parodos, the chorus describe the effects of the blight that affects the city: sickness, agricultural crisis, deaths. We already examined (section 5.I) the passage in the Getty Hexameters that envisages a similar crisis: 'a doom that brings death' threatens human beings and flocks (25-8); the city repeats 'night and day' (29) a prayer or incantation (3I); the sequence ends with an invocation to Paean at $\mathrm{GH} 32$. The chorus, in the second antistrophe of the parodos, call on Paean (OT 179-88): ${ }^{83}$

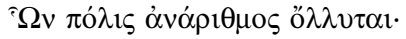

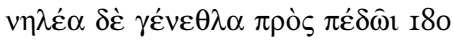

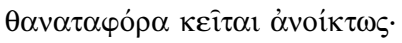

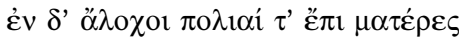

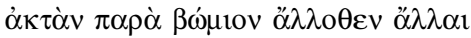

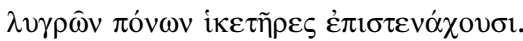



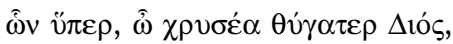

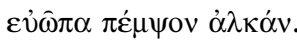

Countless are their deaths, and the city is perishing, unpitied her children lie on the ground, carried off by death, with none to lament; and by the row of altars wives and white-haired mothers on this side and on that groan as suppliants on account of their sad troubles. Loud rings out the hymn to the Healer and the sound of lamentation with it! For these things, golden daughter of Zeus, send the bright face of protection!

Not only is the situation similar (death threatens humans and animals, and the city as a

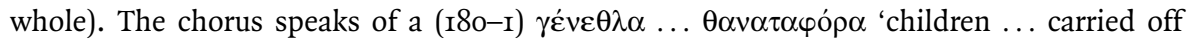



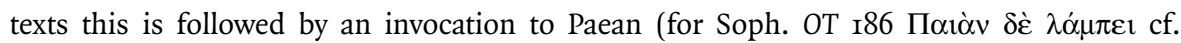


paeanic refrain (153-5n.) and the explicit reference to the paean (I87), suggests that the song should itself be characterised as a paean, a type of song with prominently apotropaic associations (4-5n.)' ${ }^{84}$ The two texts are also connected by metrical similarities. The parodos is predominantly in dactylic metres: the first strophic pair starts

83 Text and translation from Lloyd-Jones (1994) (here and in the quotation of OT 179-88 that follows in the main text). 84 Finglass (2018) 208, on Soph. OT I5I-2I5. 
and ends with hexameters, ${ }^{85}$ and the dactylic rhythm is present in the second strophic pair


corresponds to the second part of a hexameter after the caesura at the third longum.

The word $\theta \alpha v \alpha \tau \eta \varphi$ ópo $\varsigma$ is not very common in classical and archaic Greek. ${ }^{87}$ It occurs in poetry only in the Getty Hexameters and in the two passages of tragedy quoted above (Aesch. Cho. 369; Soph. OT I8I), passages which have strong verbal and content similarities to the passage in the Getty Hexameters. It is not surprising that both Aeschylus and Sophocles, when describing a crisis that affects a whole community, both alluded to ritual practices that were in actual use in the Greek world. We have here in the Oedipus Tyrannus a strong 'linguistic intimation', accompanied by references to very similar ritual and religious practices.

\section{Plato's Republic}

Plato seems to echo the language of incantation ('linguistic intimation') in his myth of Er. When the souls of the dead emerge from the cycle of purification, they encounter a prophet of Lachesis who proclaims (Resp. 6r7d6-e3):

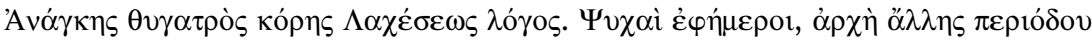

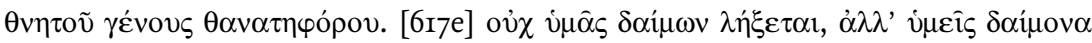

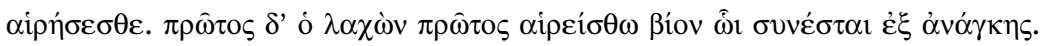

The word of Lachesis, virgin daughter of Necessity! Transient souls, the start of another mortal cycle of the human race! A daimon will not be allotted to you, but you will choose a daimon. The one who draws the first lot is to make the first choice of a life, to which he will be bound by necessity. (tr. Halliwell (I988))

Necessity, as Proclus noted, speaks in a solemn and impressive style (note the absence of articles and verbs). ${ }^{88}$ The similarities in content and language with the Getty Hexameters are

85 Finglass (2018) 209, 'Metrical analysis', interprets it as follows: 6da || 2ia 6da || - D - 4da 6da 6da |||. Finglass quotes with approval Haldane ( 1963 ) 55, who notes that the dactylic runs are 'a favourite [metre] of the paean'. On dactyls in paeans see also Käppel (1992) 77, Lucarini (2018) 33 and n. 17, and the extensive discussion of Faraone (201r),

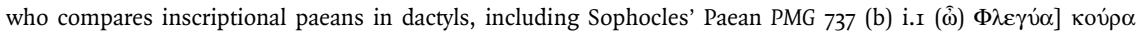

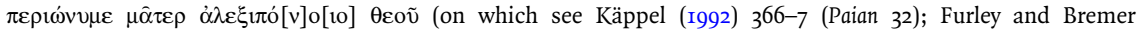
(200I) I.26I-2, II.2I9-2I; Rutherford (200I) 39), with the dactylic parodos of the Oedipus Tyrannus. Furley and Bremer (200I) II.280-9 offer a detailed discussion of the paeanic features of the parodos.

86 For the metrical analysis see Finglass (2018) 209: 2ia 2 ia an an^ $\| 4 \mathrm{da} \times D^{2}$ - ia an an^ $\|$ ia 4 da 4 da ia ia $\mid \|$.

87 These are the number of occurrences (checked on the TLG website): $\times_{I}$ in Aeschylus, $\times_{I}$ in Sophocles, $\times_{I}$ in




in Theophrastus in reference to $\varphi \alpha \dot{\alpha} \mu \alpha \kappa \alpha$ and snakes; often in Aelianus and later writers in this connection.

88 Procl. in Resp. vol. In p. 269 lines 9-I4 in Kroll (I899-I9or); the rest the commentary on this passage (until 273 line 5 Kroll) is also full of useful stylistic and philosophical observations. 
notable, not simply for the use of the word $\theta \alpha v \alpha \tau \eta \varphi$ ópos. Both texts describe the afterlife, and both mention Ananke, 'Necessity'. The Getty Hexameters speak of Persephone's garden

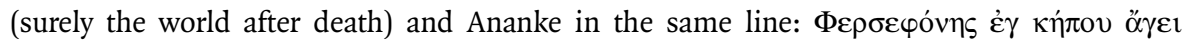

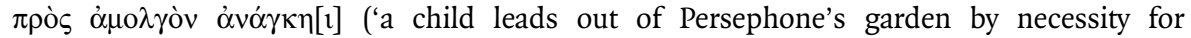
milking', 9). Plato obviously knows well the language of incantations and magic. ${ }^{89} \mathrm{He}$ here uses words that recall language used in actual magical texts..$^{\circ}$ Already Plutarch (Quaest. conv. 715c) noticed the connection between this passage of Plato and Empedocles' mention of Necessity in connection with reincarnation; ${ }^{91}$ Empedocles' Sicilian origin, and his interest in magic, are obvious points of contact with the Getty Hexameters.

\section{The Hecuba of Euripides and Carcinus}

A passage from the Getty Hexameters presents many similarities with a passage from the Hecuba of Euripides. This is the text of lines 8-I4:

†

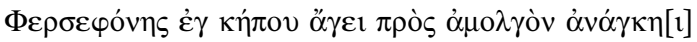

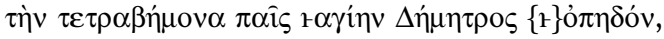
IO

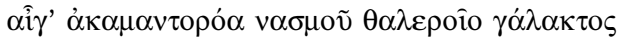

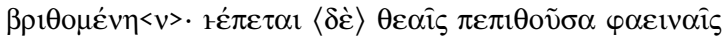





$\uparrow$... the child, from the shadowy mountains in the black-lit place,

Leads from Persephone's garden by force to its milking

The four-footed attendant of holy Demeter, IO

The goat that weighs heavy with rich milk's tireless flow.

She follows, obeying goddesses with torches ablaze.

Hecate of the crossroads, screaming obscurely

In hair-raising voice, a goddess, leads the god.

Bremmer focused on the similarity with Hec. $15 \mathrm{I}-2$, but in fact the whole sequence starting at I4I is of importance (Hec. I4I-52):

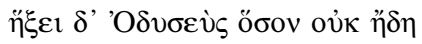

$\pi \hat{\omega} \lambda o v \dot{\alpha} \varphi \dot{\varepsilon} \lambda \xi \omega v \sigma \hat{\omega} v \dot{\alpha} \pi \grave{o} \mu \alpha \sigma \tau \hat{\omega} v$

89 See Faraone (2010), with further references.

9o For speculations about possible cosmological links between Plato's text (esp. Resp. ro) and the Getty Hexameters see Kotansky (2016) n. 33 .

9I See II6 DK = D23 in Laks and Most (2016) 374-5; cf. also Bir5 DK = Dio-Dir in Laks and Most (2016) 366-9. For a discussion of these passages see esp. Trépanier (2017), with further references. See also Empedocles' mention of a 'joyless place' in connection with a 'meadow': I2I DK= D24 in Laks and Most (2016) 374-5. 


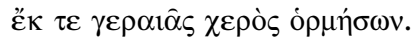

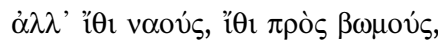

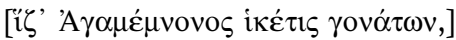

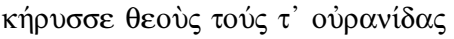



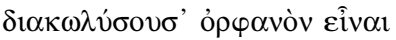

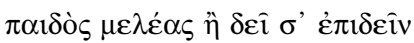



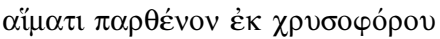

$\delta \varepsilon ı \tilde{\eta} \varsigma$ v $\alpha \sigma \mu \omega \hat{\imath} \mu \varepsilon \lambda \alpha \nu \alpha v \gamma \varepsilon \hat{\imath}$.

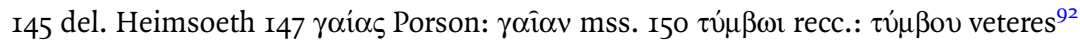

Odysseus will come almost at once to pull the filly away from your breast and hurry her from your aged embrace. Come, go to the temples, go to the altars, [sit as suppliant at Agamemnon's knees,] loudly invoke both the gods of heaven and those beneath the earth: for either prayers shall prevent your being orphaned of your child or you must live to see the maiden thrown forward on the tomb, crimsoned with the blood welling dark and gleaming from her gold-decked throat. (tr. Collard (I99I) adapted)

Both Janko and Bremmer noted the verbal similarities but did not explore the importance of the context. There are several points of contact. Polyxena is compared to an animal lead away from the breast of the mother, a rather incongruous image if one thinks of the age of Hecuba. This is very similar to the image of the goat who has copious milk and is lead away from the garden; it also recalls the 'goat rushing to the milk' in the so-called Orphic Golden tablets. ${ }^{93}$ Both the Hecuba passage and the Getty Hexameters envisage the necessity of prayers to avert evil and death. The adjective $\mu \varepsilon \lambda \alpha v \alpha v \gamma \varepsilon \hat{i}$ " "dark-shining” is a vivid description of the gleaming of a dark liquid, imitating the epic phrases

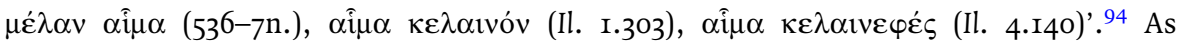
Janko notes:

The non-traditional word $\mu \varepsilon \lambda \alpha v \alpha v \gamma \eta \dot{n}$ is first attested in Euripides' Hecuba I52, $v \alpha \sigma \mu \hat{\omega} \imath \mu \varepsilon \lambda \alpha v \alpha v \gamma \varepsilon \hat{i}$. It is very striking indeed that $v \alpha \sigma \mu$ ó $\varsigma$ occurs here in the very next line, as if its composer knew this passage of Euripides (the word does indeed seem like one of the latter's creations) - unless of course Euripides is creating a

\footnotetext{
92 Text and apparatus from Battezzato (2018), slightly adapted.

93 See F 485.3-5 with Bernabé (2005) 46-9 ad loc., with extensive bibliography; 486.3-5, 487.4, 488.10; Ferrari (2004) 98-IO2 = (2007) I46-50.

94 Battezzato (2018) ad loc.
} 
tragic variation on the phrasing of this very poem, a stream of blood instead of a stream of milk; for $\mu \varepsilon \lambda \alpha v \alpha v \gamma \eta$ s seems more obviously applicable to a place in the underworld than to blood. ${ }^{95}$

This works much better if it is Euripides who is offering a variation on the passage present in the Getty Hexameters. Blood alludes to death and the afterlife, and the 'stream' of blood recalls the filly/breast image of Hec. I42, and the milk of the goat in GH II.

In fact, Euripides uses similar oxymoronic images already in the Alcestis, in another passage which recalls the language of the Getty Hexameters (Alc. 259-62):

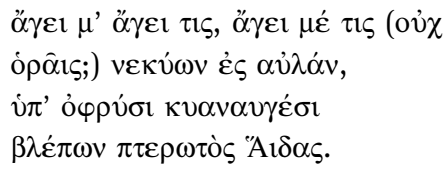

Someone is taking, is taking me (don't you see him?) away to the court of the dead. It is winged Hades, glowering from beneath his dark brows. (tr. Kovacs (1994))

The adjective $\kappa v \alpha v \alpha v \gamma \varepsilon \dot{\sigma l}$ ('dark gleaming'), which describes the eyebrows of Hades, is a variation on $\mu \varepsilon \lambda \alpha v \alpha v \gamma \varepsilon$ i ('dark gleaming') used in Hec. 152 in reference to the afterlife..$^{96}$

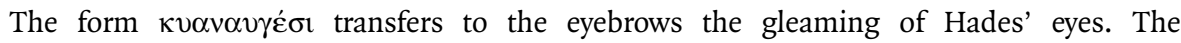
repetition of ö $\gamma \varepsilon 1$ and the mention of the 'hall of the dead' recall the 'garden of Persephone' and the verb ö $\gamma \varepsilon 1$ of GH 9. The oxymoron for the description of Hades is

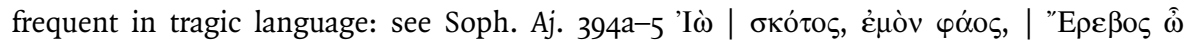


$\mu \varepsilon \lambda \alpha \mu \varphi \alpha \dot{\varepsilon} \varsigma . . . \check{\varepsilon} \rho \varepsilon \beta 0{ }^{.9}{ }^{8}$ The 'light' of Erebos is in fact darkness. ${ }^{99}$ As mentioned at the beginning of the article (above, section I), the fourth-century BC tragic poet Carcinus alludes to this traditional language in his description of Persephone's journey to the

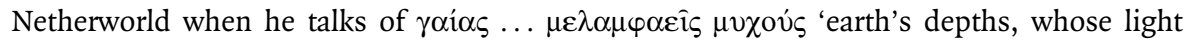
is darkness' (70 F 5.3 TrGF; tr. Oldfather (1939)).

The occurrence of so many similar phrases in reference to the oxymoronic 'dark light' of Hades or Erebos makes it likely that the adjective $\mu \varepsilon \lambda \alpha v \alpha v \gamma \eta \dot{n}$, like $\mu \varepsilon \lambda \alpha \mu \varphi \alpha \eta \dot{s}$ and


the phrase in GH $8 \mu \varepsilon \lambda \alpha v \alpha v \gamma \varepsilon$ i $\chi \omega \dot{\rho} \omega t$ uses it in the original context.

95 Janko (2013) 47.

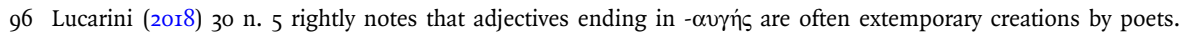



97 Translation from Finglass (2011).

98 Kannicht (I969) ad Eur. Hel. 518-22 inclines towards an interpretation of the second part of these compound

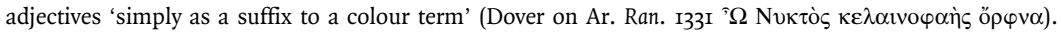

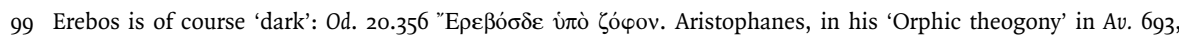

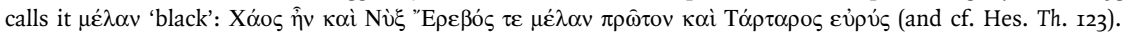


As Scott Scullion notes (personal communication), Euripides uses these adjectives in a pointed oxymoronic way, whereas the Getty Hexameters seem to use $\mu \varepsilon \lambda \alpha v \alpha v \gamma \varepsilon$ éi in the straightforward meaning 'black', in contrast with the light of the 'bright goddesses' (GH

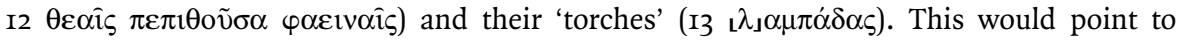
Euripidean effective manipulation of traditional magic and cultic language.

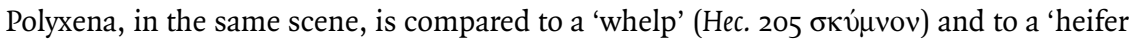

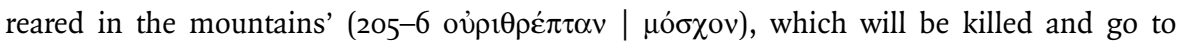
Hades. ${ }^{\text {Ioo }}$ This again recalls the goat coming 'down from the mountains' for milking mentioned in GH 8. Later in the play, the sacrifice of Polyxena is described in terms that clearly allude to the narration of the sacrifice of Iphigenia in the Agamemnon. ${ }^{\text {Ior }}$ No ritual perspective is open for the chorus of Hecuba in the time frame of the play, which is set in a place where no divine cult is performed. For chronological and poetic reasons, it is unlikely that the Getty Hexameters reworked phrases from Euripides (and they definitely do not allude to Euripides). In Euripides the 'linguistic intimation' of texts on the afterlife is stronger in the Alcestis than in the Hecuba. On the other hand, Carcinus is clearly alluding to the language of mystery cults ('linguistic intimation') and possibly to the very phrase used in the Getty Hexameters (and other similar early texts?) ('textual allusion').

\section{The Chaldaean Oracles, Synesius and Iamblichus}

The phrase had a long and successful life in late antiquity. The adjective 'dark-lit', Bremmer notes, 'occurs otherwise only in the Chaldean Oracles (fr. $\mathrm{I}_{3}$ des Places: with thanks to Radcliffe Edmonds) and the Orphic Argonautica (513)'. ${ }^{\text {IO2 }}$ Bremmer does not explore the relation between these texts and the Getty Hexameters, but it is easy to observe that these occurrences prove that the text of the Getty Hexameters was read and imitated in the Imperial age. We know for certain from an Egyptian papyrus, $\mathrm{K}$, that the lines about the 'dark-lit place' were still copied in the second or even third century AD. ${ }^{103}$ Several late antique passages appear to be clear textual allusions to the phrase found in the Getty Hexameters (and in other texts). The phrase about the 'dark-lit place' from the magic tradition is an exemplar-model for the Chaldaean Oracles, and that in turn (and in

IOo On the text of lines 205-Io see the discussion in Battezzato (2018) ad loc.

Ior See Battezzato (2018) on 526, 544-5, 558-6I.

I02 Bremmer (2013) 25 .

I03 $\mathrm{K}$ is the siglum used in Janko (2015). For more detailed information see Jordan (I988) (who dates the document to the third-fourth century AD); Daniel and Maltomini (I990) I93-204, no. 49, lines 65-73 (dated to the second-third century AD). Cf. fr. 830 a in Bernabé (2005) 35I-3. On its provenance see Bernabé (20I3) 28 n. 9. A conjecture by


hymn for Isis, dating to the first century BC or first century AD, and found in Andros (IG xII.5.739; the phrase occurs in line 43). This phrase would refer to Hades. However, Peek (1930) 45 defends the transmitted text $\mu \varepsilon \lambda \alpha \dot{\mu} \mu \alpha \rho$ óv $\tau \varepsilon$ (linked to another word in the text); Peek's text is reproduced without detailed textual discussion by Totti (I985) 6 and Bricault (2005) 363 and 366. 
combination with the phrase from the magic tradition) is an exemplar-model for passages in Synesius and Iamblichus.

Fragment $163.1-3$ from the Chaldaean Oracles runs as follows:





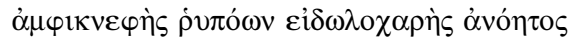

Do not stoop below into the dark-gleaming world beneath which an abyss is spread, forever formless and invisible, dark all around, foul, delighting in images, without reason. $^{\text {I04 }}$

We should keep in mind the fact that the speaker of at least some Chaldaean Oracles is the goddess Hecate. ${ }^{\text {I05 }}$ The Chaldaean Oracles are normally dated to the second century $A D ;{ }^{106}$ this fragment is transmitted by Synesius, On Dreams 7.5, as well as by Psellus, Damascius and Proclus. ${ }^{107}$ The 'dark-gleaming world' is the sublunar world, from which the souls should be able to detach themselves, and the 'abyss' is Tartarus. ${ }^{108}$ The adjective implicitly compares the sensible world with the afterlife. The Platonic image of the cave also contributes to the idea that the world is a 'dark-lit place', and that light only shines in the ideal world of the Forms.

Synesius comments on fr. $\mathrm{I}_{3} 3$ in the context of a discussion of the afterlife. He claims that 'the oracles' (i.e. the Chaldaean Oracles) tell that dreams are comparable to the images seen in the afterlife (7.2); he quotes Plato's Laws 653a and Heraclitus (7.3), and discusses the separation of soul and body at death and the importance of mystery cults for the soul (7.4). He then quotes the 'sacred logoi' (i.e. the Chaldaean Oracles again) and discusses Lethe and the descent of the soul towards the material world. He quotes again the Chaldaean 'logos' in chapter 9 , this time in a form that clearly recalls that found in the magical tradition of the Getty Hexameters (Synesius, De insomniis 9.I):

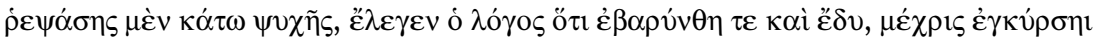



when the soul descends, the logos says that it becomes heavy and plunges down, until it reaches the dark-shining and all-around-dark place.

I04 Translation from Majercik (1989) III (Majercik (2013), presented as a 'second edition', is in fact a reprint of the first edition). See Des Places (1971) I06; Lewy (1978) 294-300.

I05 See Des Places (I97I) ro; Majercik (I989) I, 4; Johnston (I990) I-4, esp. I n. 2 (frr. 38, 53, 58, 72, I46-8, certainly spoken by Hecate); Johnston (2007) I88. On Hecate in the religious and philosophical world of the Chaldaean Oracles see Lewy (1978) 83-98.

Io6 See Des Places (1971) 7; Majercik (1989) I-3; Johnston (2007) I88.

I07 See Des Places (1971) ro6.

I08 See Lewy (I978) 294-300. Majercik (I989) 20I-2 identifies both the kosmos of line 2 and the bathos which lies under the cosmos with 'matter'; Des Places (I97I) Io6 n. I identifies the bathos with 'matter'. 
Synesius seems to have known the phrase as attested in the Getty Hexameters. He imitates the Chaldaean Oracles (not the Getty Hexameters) in his first Hymn, lines 297-30I:

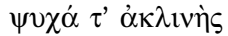

$$
\begin{aligned}
& \kappa \alpha i ̀ ~ \kappa \lambda \iota v o \mu \varepsilon ́ v \alpha
\end{aligned}
$$

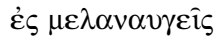

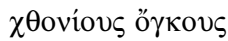

Both the soul that is not inclined (towards the material world) and the soul that is inclined towards the dark-gleaming earthly material substance (sing the praise of the Lord).

Here Synesius glosses the phrase with the adjective $\chi \theta$ ovious 'earthly', so as to make sure that the adjective is understood (as the riddling text of the Chaldaean Oracles implies) to refer to the world we live in, not the afterlife (as in the magical tradition).

One last Neoplatonic/Neopythagorean imitation of the phrase is found in Iamblichus, On the Pythagorean Life. Iamblichus claims that Pythagoras presented himself as a divine man and that other human beings, being unable to look directly at the gods, should look at him to understand the nature of the divine. Similarly (67),

when people cannot look directly at the sun, because of the brilliance of its rays, we find ways to show them an eclipse, with a deep container of water or a film of pitch or

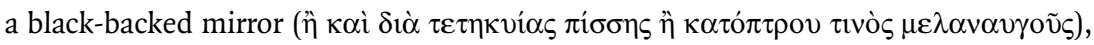
sparing their weak eyesight. (tr. Clark (I989))

Pythagoras himself is the 'black-shining' mirror that allows humans to see the gods. ${ }^{\text {Io9 }}$ This passage clearly alludes to Plato's cave myth (humans cannot look at reality), to Plato's comparing imitation with mirrors (Resp. 596d-e) and to the myth of Er (Pythagoras himself descended from heaven). ${ }^{\text {IIO }}$ Pythagoras thus can provide humans with access to the divine, and help them avoid descending into base types of life.

These passages show how the phrase describing the 'black-shining places' survived for a long time in poetry and prose that discussed the fate of the soul and mystery cults. It is likely that both the author of Chaldaean Oracles fr. $\mathrm{I}_{3}$ Des Places and Synesius knew the version of the text attested in the Getty Hexameters and in papyrus $\mathrm{K}$.

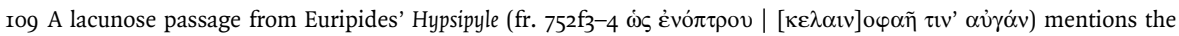



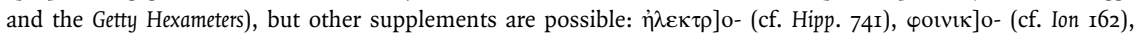

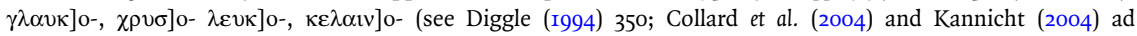
loc.). On mirrors in Neoplatonism and the connection of the motif of mirrors with Pl. Ti. 7ra-d (the liver as mirror) see Sheppard (2003).

IIo On imitation and mirrors see Halliwell (2002) II8-47; Cain (2012). 


\section{I0. Conclusions}

The complex allusions of tragedy to magic texts ('linguistic intimations') suggest that some linguistic elements that surface in the Getty Hexameters (esp. GH $8 \mu \varepsilon \lambda \alpha v \alpha v \gamma \varepsilon$ éi $\chi \omega \dot{\rho} \omega t, 26-7$

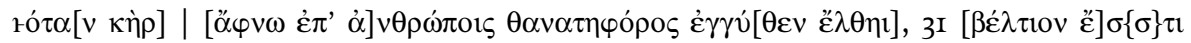
$\pi$ ó $\lambda \varepsilon 1)$ where known and imitated in Greek tragedy and by Plato.

The Getty Hexameters, though, are not (as far as we know) an authoritative, stable text, nor were they attributed to a real (Pythagoras) ${ }^{\mathrm{III}}$ or fictional (Orpheus? Musaeus?) author. Sections of the texts that surface in the Getty Hexameters were being used and adapted in various forms in the classical age. Some tragic and philosophical texts allude to the (until recently unknown) sub-genre to which the Getty Hexameters belong (incantation-paean in hexameters) ('genre intimation') and to specific phrases ('linguistic intimation' and, possibly, in one case, 'textual allusion') used in this sub-genre. The tragic performance presents itself as reperforming (or attempting to reperform) on stage the incantation rituals that it alludes to. It is in the nature of the tragic text to englobe discourses and speech-genres belonging to different traditions; it is also in its nature to stress the ritual failures of chorus and characters. ${ }^{\mathrm{II}}$ It is unlikely that the 'short story' about the goat of GH 8-I4 alludes to/depends on the text of the Hecuba (no 'textual allusion' here). The similarities in language probably derive from a phrase used of Hades/Erebos in the Getty Hexameters, a phrase which was known to Euripides, and that was going to be in continuous use from (at least) the fifth century $\mathrm{BC}$ to the fourth century $\mathrm{AD}$, resurfacing in authors who discussed the afterlife and mystery cults. This new antecedent of tragic texts shows how dense the web of allusions ('genre intimations', 'linguistic intimations', 'textual allusions') in the works of the tragic authors is, and how much richer the interpretation becomes whenever we acquire new material that expands our knowledge of genres, ritual practices and language in classical antiquity.

\section{Works cited}

Allan, W. (2008) Euripides: Helen, Cambridge.

Antonetti, C. (ed.) (2018a) Gli esametri Getty e Selinunte. Testo e contesto, Alessandria.

(20I8b) 'Gli esametri Getty e Selinunte. Contesto storico e intertestualità culturale', in Antonetti (2018a) 109-30.

Austin, C. and S. D. Olson (2004) Aristophanes: Thesmophoriazusae, Oxford.

Battezzato, L. (2005) 'Le vie dell'Hades e le vie di Parmenide. Filologia, filosofia e presenze femminili nelle lamine d'oro "orfiche"', SemRom 8, 67-99.

(2018) Euripides: Hecuba, Cambridge.

Bernabé, A. (2005) Poetarum epicorum Graecorum testimonia et fragmenta. Pars ii: Orphicorum et orphicis similium testimonia et fragmenta. Fasciculus 2, Munich and Leipzig.

(2013) 'The Ephesia Grammata: genesis of a magical formula', in Faraone and Obbink (2013a) 7I-95.

III Janko (2016) I27 suggests that the 'archetype' of the Orphic Golden Leaves was written by Pythagoras.

II2 See e.g. Zeitlin (1965), (1970), (I996); Mikalson (1989). 
Bettarini, L. (2005a) 'Una nuova defixio di Selinunte?', ZPE I5I, 253-8.

(2005b) Corpus delle defixiones di Selinunte. Edizione e commento, Alessandria.



Bremmer, J. N. (2013) 'The Getty hexameters: date, author, and place', in Faraone and Obbink (2013a), 2I-9.

(2014) Initiation into the mysteries of the ancient world, Berlin.

Bricault, L. (2005) Recueil des inscriptions concernant les cultes isiaques. Volume i, Paris.

Brown, A. (2018) Aeschylus: Libation bearers, Liverpool.

Burkert, W. (I962) 'ГOH $\Sigma$ : zum Griechischen "Schamanismus", RhM I05, 36-55.

(I987) Ancient mystery cults, Cambridge, MA and London.

(2006) Mystica, Orphica, Pythagorica, ed. F. Graf, Göttingen.

Cain, R. B. (2012) 'Plato on mimesis and mirrors', Philosophy and Literature 36, 187-95.

Caliva, K. (2016) 'Speech acts and embedded narrative structure in the Getty hexameters', ARG I7, I39-64.

Cassio, A. C. (2005) 'I dialetti eolici e la lingua della lirica corale', in F. Bertolini and F. Gasti (eds.),

Dialetti e lingue letterarie nella Grecia arcaica, Pavia, $13-44$.

(20I6) Storia delle lingue letterarie greche, 2 nd edn, Florence.

Cingano, E. (2018) 'A fresh look at the Getty hexameters: style, diction, tradition and context (Part one)', in Antonetti (2018a) 23-5I.

Clark, G. (I989) Iamblichus: On the Pythagorean life, Liverpool.

Collard, C. (I99I) Euripides: Hecuba, Warminster.

Collard, C., M. Cropp and J. Gibert (2004) Selected fragmentary plays. Volume ii, Warminster.

Collins, D. (2008) Magic in the ancient Greek world, Malden, MA and Oxford.

Conte, G. B. (1986) The rhetoric of imitation: genre and poetic memory in Virgil and other Latin poets, Ithaca.

Curti, M. (2012) 'Echi letterari di pratiche magiche in Eschilo', Eikasmos 23, 67-85.

D’Alessio, G. B. (2009) 'Defining local identities in Greek lyric poetry', in I. Rutherford and R. Hunter (eds.), Wandering poets in ancient Greek culture: travel, locality and pan-Hellenism, Cambridge, I37-67.

Daniel, R. W. and F. Maltomini (1990) Supplementum magicum. Volume i, Opladen.

Davies, M. (2016) The Aethiopis: neo-neoanalysis reanalyzed, Washington, DC.

Del Monaco, L. (2012) 'A $\sigma \kappa \iota ~ K \alpha \tau \alpha \sigma \kappa \imath$. Ephesia Grammata da Locri Epizefirii', ZPE I83, I29-39.

Denniston, J. D. and D. L. Page (1957) Aeschylus: Agamemnon, Oxford.

Des Places, É. (I97I) Oracles chaldaïques. Avec un choix de commentaires anciens, Paris.

Dickie, M. (200I) Magic and magicians in the Greco-Roman world, London.

Diggle, J. (I970) Euripides: Phaethon, Cambridge.

(I994) Euripidea: collected essays, Oxford.

Dimartino, A. (2015) 'La lex sacra di Selinunte. Analisi paleografica e prospettive storico-religiose di una laminetta iscritta', in Iannucci, Muccioli and Zaccarini (2015) $135-63$.

Edmonds, R. G. (2013) 'The Ephesia Grammata: logos Orphaikos or Apolline alexima pharmaka?' in Faraone and Obbink (2013a) 97-106.

(2019) Drawing down the moon: magic in the ancient Greco-Roman world, Princeton.

Erbse, H. (ed.) (r969-88) Scholia Graeca in Homeri Iliadem: scholia vetera, 7 vols., Berlin.



(1994) 'Deianeira's mistake and the demise of Heracles: erotic magic in Sophocles' Trachiniae', Helios 2I, II5-35.

(1999) Ancient Greek love magic, Cambridge, MA and London.

(2008) 'Mystery cults and incantations: evidence for Orphic charms in Euripides' Cyclops 646-48?', RhM I5I, I27-42.

(2010) 'A Socratic leaf charm for headache (Charmides 155 b-I57c), Orphic gold leaves, and the ancient Greek tradition of leaf amulets', in J. Dijkstra, J. Kroesen and Y. Kuiper (eds.), Myths, martyrs, and modernity: studies in the history of religions in honour of Jan N. Bremmer, Leiden, I45-66. 
(20II) 'An Athenian tradition of dactylic Paeans to Apollo and Asclepius: choral degeneration or a flexible system of non-strophic dactyls?', Mnemosyne 64, 206-31.

(2013) 'Spoken and written boasts in the Getty Hexameters: from oral composition to inscribed amulet', in Faraone and Obbink (2013a) 57-70.

Faraone, C. A. and D. Obbink (2013a) The Getty hexameters: poetry, magic, and mystery in ancient Selinous, Oxford.

(2013b) 'Greek text and translation of the Getty Hexameters, in Faraone and Obbink (2013a) Iо-3.

Favi, F. (2019) 'Epicharmus and choral lyric poetry: a reappraisal of old and new evidence', in E. Passa and O. Tribulato (eds.), The paths of Greek: at the crossroads between literature, linguistics and epigraphy, Berlin and Boston, I49-73.

Ferrari, F. (2004) 'Sotto il velame. Le formule misteriche nelle lamine del timpone piccolo di Thurii', SCO 50, 89-105.

(2007) La fonte del cipresso bianco. Racconto e sapienza dall'Odissea alle lamine misteriche, Turin.

(2008) 'Per leggere le lamine misteriche', Prometheus 34, I-26, 97-II2.

Finglass, P. J. (20II) Sophocles: Ajax, Cambridge.

(2018) Sophocles: Oedipus the King, Cambridge.

Finglass, P. J. and M. Davies (2014) Stesichorus: the poems, Cambridge.

Fraenkel, E. (I9I8) 'Lyrische Daktylen', RhM 72, I6I-97, 32I-52.

(1950) Aeschylus: Agamemnon. Edited with a commentary by Eduard Fraenkel, Oxford.

(1964) Kleine Beiträge zur klassischen Philologie, 2 vols., Rome.

Friis Johansen, H. and E. W. Whittle (I980) Aeschylus: The suppliants, 3 vols., Copenhagen.

Furley, W. D. (2019) 'Magic and mystery at Selinus: another look at the Getty Hexameters', in L. M.

Bortolani, W. D. Furley, S. Nagel and J. F. Quack (eds.), Cultural plurality in ancient magical texts and practices: Graeco-Egyptian handbooks and related traditions, Tübingen, 42-6I.

Furley, W. D. and J. M. Bremer (200I) Greek Hymns: a selection of Greek religious poetry from the arcaic to the Hellenistic period, 2 vols., Tübingen.

Garvie, A. F. (1986) Aeschylus: Choephori, Oxford.

Graf, F. (1997) Magic in the ancient world, Cambridge, MA.

Griffith, M. (I995) 'Brilliant dynasts: power and politics in the "Oresteia”, CA I4, 62-I29.

(1999) Sophocles: Antigone, Cambridge.

Haldane, J. A. (I963) 'A Paean in the Philoctetes', CQ 13, 53-6.

Halliwell, S. (1988) Plato: Republic 10, Warminster.

(2002) The aesthetics of mimesis: ancient texts and modern problems, Princeton.

Hansen, P. A. (1983) Carmina epigraphica Graeca saeculorum viii-v a. Chr. n., Berlin and New York.

Herington, J. (1985) Poetry into drama: early tragedy and the Greek poetical tradition, Berkeley.

Hinds, S. (1998) Allusion and intertext: dynamics of appropriation in Roman poetry, Cambridge.

Hinge, G. (2006) Die Sprache Alkmans: Textgeschichte und Sprachgeschichte, Wiesbaden.

Hirschberger, M. (2004) Gynaikōn Katalogos und Megalai Ēhoiai: ein Kommentar zu den Fragmenten zweier hesiodeischer Epen, Munich.

Hollmann, A. (2003) 'A curse tablet from the Circus at Antioch', ZPE I45, 67-82.

Hunter, R. L. (I999) Theocritus: A Selection. Idylls 1, 3, 4, 6, 7, 10, 11 and 13, Cambridge.

Iannucci, A., F. Muccioli and M. Zaccarini (2015) La città inquieta. Selinunte tra lex sacra e defixiones, Milan. Jameson, M. H., D. R. Jordan and R. D. Kotansky (I993) A lex sacra from Selinous, Durham, NC.

Janko, R. (I984) 'Forgetfulness in the golden tablets of memory', CQ 34, 89-Ioo.

(2013) 'The hexametric incantations against witchcraft in the Getty Museum: from archetype to exemplar' in Faraone, Obbink (2013b) 3I-56.

(2015) 'The hexametric Paean in the Getty Museum: reconstituting the archetype', ZPE 193, I-Io.

(2016) 'Going beyond multitexts: the archetype of the Orphic gold leaves', CQ 66, Ioo-27.

Johnston, S. I. (I990) Hekate soteira: a study of Hekate's role in the Chaldean oracles and related literature, Atlanta, GA. 
(2007) 'Oracula Chaldaica', in H. Cancik, H. Schneider and C. F. Salazar (eds.), Brill's New Pauly: Antiquity. Volume x: Obl-Phe, I88-9.

(2014) 'Goddesses with torches in the Getty Hexameters and Alcman fr. 94', ZPE I9I, 32-5.

Jordan, D. R. (I988) 'A love charm with verses', ZPE 72, 245-59.

(I992) 'The inscribed lead tablet from Phalasarna', ZPE 94, I9I-4.

Jordan, D. R. and R. D. Kotansky (20II) 'Ritual Hexameters in the Getty Museum: preliminary edition', ZPE I78, 54-62.

Jordan, D. R., G. Rocca and L. Threatte (2014) 'Una nuova defixio dalla Sicilia (Schøyen Collection MS I700)', ZPE I88, 23I-6.

Kannicht, R. (I969) Euripides: Helena, Heidelberg.

(2004) Tragicorum Graecorum fragmenta. Volume v: Euripides, Göttingen.

Käppel, L. (1992) Paian: Studien zur Geschichte einer Gattung, Berlin and New York.

Kindt, J. (2012) Rethinking Greek religion, Cambridge.

Kingsley, P. (1995) Ancient philosophy, mystery, and magic: Empedocles and Pythagorean tradition, Oxford.

Kotansky, R. D. (2016), 'Getty Hexameters, the', in T. Whitmarsh (ed.), The Oxford classical dictionary, Oxford, online at: https://oxfordre.com/classics/view/ro.ro93/acrefore/9780199381135.00I.00oI/acrefore978019938I135-e-8123.

Kotansky, R. D. and J. Curbera (2004) 'Unpublished lead tablets in the Getty Museum', Mediterraneo Antico. Economie, Società, Culture 7, 68I-9I.

Kovacs, D. (1994) Euripides: Cyclops, Alcestis, Medea, Cambridge, MA.

Kroll, W. (I899-I9or) Procli Diadochi in Platonis Rem publicam commentarii, 2 vols., Leipzig.

Laks, A. and G. W. Most (2016) Early Greek philosophy. Volume v: Western Greek thinkers. Part 2, Cambridge, MA.

Lapatin, K. (2013) 'Preface', in Faraone and Obbink (2013a) v.

Lewy, H. (1978) Chaldaean oracles and theurgy: mysticism magic and Platonism in the later Roman empire, new edn by Michel Tardieu, Paris.

Lloyd-Jones, H. (I975) 'On the Orphic tablet from Hipponion', PP 30, 225-6.

(1994) Sophocles: Ajax, Electra, Oedipus Tyrannus, Cambridge, MA and London.

(1996) Sophocles: fragments, Cambridge, MA.

Lucarini, C. M. (2018) 'Il nuovo peana misterico-pitagorico di Selinunte', ZPE 205, 24-37.

(2019) La genesi dei poemi omerici, Berlin and Boston.

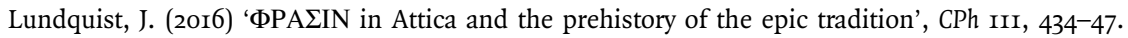

Maehler, H. (2004) Bacchylides: a selection, Cambridge.

Majercik, R. D. (I989) The Chaldean oracles: text, translation, and commentary, Leiden.

(2013) The Chaldean oracles: text, translation and commentary, 2nd edn, Westbury.

Marconi, C. (2018) 'La dea del Tempio B', in Antonetti (2018a) 179-200.

Martin, G. (2018) Euripides: Ion, Berlin.

Mastronarde, D. J. (I994) Euripides: Phoenissae, Cambridge.

McClure, L. (1996) 'Clytemnestra's binding spell (Ag. 958-974)', CJ 92, I23-40.

(1999) Spoken like a woman: speech and gender in Athenian drama, Princeton.

Medda, E. (2017) Eschilo: Agamennone, 3 vols., Roma.

Merkelbach, R. and M. L. West (I967) Fragmenta Hesiodea, Oxford.

Mikalson, J. D. (I989) 'Unanswered prayers in Greek tragedy', JHS Io9, 8I-98.

Morrison, A. D. (2020) Apollonius Rhodius, Herodotus and historiography, Cambridge.

Most, G. W. (2007) Hesiod: The shield, Catalogue of women, other fragments, Cambridge, MA.

Mueller, M. (20II) 'Phaedra's defixio: scripting Sophrosune in Euripides' Hippolytus', ClAnt 30, I48-77.

Obbink, D. (2013) 'Poetry and the mysteries', in Faraone and Obbink (2013a) I7I-84.

Ogden, D. (2009) Magic, witchcraft, and ghosts in the Greek and Roman worlds: a sourcebook, 2nd edn, Oxford.

Oldfather, C. H. (I939) Diodorus of Sicily. Volume iii: Books iv (continued) 59-viii, Cambridge, MA.

Page, D. L. (1972) Aeschyli tragoediae, Oxford. 
Parker, R. (2005) Polytheism and society at Athens, Oxford.

Peek, W. (1930) Der Isishymnus von Andros und verwandte Texte, Berlin.

Prauscello, L. (2019) 'Greek lyric Kunstsprache between pan-Hellenism and epichoric influence: two case studies', in Willi (2019) 55-84.

Radt, S. L. (I999) Tragicorum Graecorum fragmenta (TrGF). Volume iv: Sophocles, 2nd edn, Göttingen.

(2009) Tragicorum Graecorum fragmenta (TrGF). Volume III: Aeschylus, 2nd edn, Göttingen.

Raeburn, D. and O. Thomas (20II) The Agamemnon of Aeschylus: a commentary for students, Oxford.

Richardson, N. J. (1974) The Homeric Hymn to Demeter, Oxford.

Robertson, N. (2010) Religion and reconciliation in Greek cities: the sacred laws of Selinus and Cyrene, Oxford and New York.

Rocca, G. (2009) Nuove iscrizioni da Selinunte, Alessandria.

Rutherford, I. (200I) Pindar's Paeans: a reading of the fragments with a survey of the genre, Oxford.

(2013) 'The immortal words of Paean', in Faraone and Obbink (2013a) 157-69.

Sfameni Gasparro, G. (I986) Misteri e culti mistici di Demetra, Roma.

Sheppard, A. (2003) 'The mirror of imagination: the influence of Timaeus 7oe ff.', BICS 46, $203-\mathrm{I} 2$.

Sier, K. (I988) Die lyrischen Partien der Choephoren des Aischylos: Text, Übersetzung, Kommentar, Stuttgart.

Snell, B. and R. Kannicht (1986) Tragicorum Graecorum fragmenta (TrGF). Volume i: Didascaliae tragicae, catalogi tragicorum et tragoediarum, testimonia et fragmenta tragicorum minorum, 2nd end, Göttingen.

Sommerstein, A. H. (2008) Aeschylus: Oresteia. Agamemnon, Libation-bearers, Eumenides, Cambridge, MA.

Swift, L. A. (2010) The hidden chorus: echoes of genre in tragic lyric, Oxford.

Taplin, O. (I977) The stagecraft of Aeschylus: the dramatic use of exits and entrances in Greek tragedy, Oxford.

Timpanaro, S. (2005) The genesis of Lachmann's Method, trans. G. W. Most, Chicago.

Totti, M. (1985) Ausgewählte Texte der Isis- und Sarapis-Religion, Hildesheim.

Trépanier, S. (2017) 'From Hades to the stars: Empedocles on the cosmic habitats of soul', ClAnt 36, 130-82.

Tribulato, O. (2018a) 'Il dialetto di Himera nel contesto dell'area dello Stretto', Linguarum Varietas 7, I63-78.

(2018b) 'Writing and language in the Getty Hexameters', in Antonetti (2018b) 5-20.

Uhlig, A. (2019) Theatrical reenactment in Pindar and Aeschylus, Cambridge.

Wachter, R. (200I) Non-Attic Greek vase inscriptions, Oxford.

Weiss, N. A. (2018) The music of tragedy: performance and imagination in Euripidean theater, Berkeley.

West, M. L. (1975) 'Zum neuen Goldblättchen aus Hipponion', ZPE I8, 229-36.

(I990a) Studies in Aeschylus, Stuttgart.

(I99ob) Aeschyli tragoediae cum incerti poetae Prometheo, Stuttgart.

(2000) 'Iliad and Aethiopis on the stage: Aeschylus and son', CQ 50, 338-52.

(2013) Hellenica: selected papers on Greek literature and thought. Volume II: Lyric and drama, Oxford.

Wilamowitz-Moellendorff, U. v. (IgI4) Aeschyli tragoediae, Berlin.

Willi, A. (2008) Sikelismos: Sprache, Literatur und Gesellschaft im Griechischen Sizilien (8.-5. Jh. v. Chr.), Basle.

(ed.) (2019) Formes et fonctions des langues littéraires en Grèce ancienne. Neuf exposés suivis de discussions, Vandœuvres.

Zeitlin, F. I. (1965) 'The motif of the corrupted sacrifice in Aeschylus' Oresteia', TAPhA 96, 463-508.

(1970) 'The Argive festival of Hera and Euripides' Electra', TAPhA Ior, 645-69.

(1996) Playing the other: gender and society in classical Greek literature, Chicago.

Zografou, A. (2010) Athanassia, Chemins d'Hécate. Portes, routes, carrefours et autres figures de l'entre-deux, Liège. 